\title{
THE ROLE OF THE ARCHITECT IN DESIGNING BRIDGES AS AN AESTHETIC AND DEVELOPMENTAL ELEMENT WITHIN THE CITY
}

\author{
Magdy Kasem \\ Architecture Engineering Department, Faculty of Eng., Al- Azhar University, Cairo, Egypt \\ Received :26 Dec. $2021 \quad$ Accepted:29 Dec. 2021
}

\begin{abstract}
:
Bridges and upper intersections of all kinds are considered to be of great importance in the urban and architectural formation inside and outside cities. It was common in some countries to depend only on structural engineers without interference of the architect in some of the designs. And mostly this conviction is untrue, in which as a result there are structures of bridges that distorted the view inside and outside cities, and some of which became an obstacle in developing some areas causing visual pollution as well. That's why the research deals with this issue and the role of the architect in designing these structures as well as how to take advantage of the designs and implementing those bridges to be an edifice with aesthetic and engineering addition and to benefit from them economically, touristically, functionally and environmentally to serve the society and the place where they are implemented. As constructing bridges has become one of the most difficult and most accurate achievements in terms of design, and some of which have gained their historical importance, including What affected the region and the environment in which it was implemented, in addition to that, the use of modern technology and modern construction systems in its development, and it became a symbol of the technological development of the country. The role of these bridges led to increasing the interest in these structures, and developing a relationship between designers and users, not only for structural engineering, but also for the necessity of the intervention of architecture in its designs as a result of this distinction. It became necessary to study its aesthetic impact on its surroundings and the role of the architect in these types of designs. Generally the need tends for studies on the aesthetics of bridges and their designs, and the designer dealing with several visual elements during the design process, in which should be selected with high accuracy to create a piece of art that fits the site where the bridge is implemented in addition to apply all the necessary functional requirements For design. The research deals with addressing the importance of the role of the architect in designing and the needed requirements for these designs and providing the element of beauty with its requirements in their design.
\end{abstract}


And studying the use of these facilities in providing an economic return and community development in terms of cultural, social, sports and other aspects. The study includes some of the local models implemented in the Greater Cairo region and international models to see what has been implemented and Attempting to benefit from it in Egypt, so the research deals with looking at the experience of those implemented bridges and clarifying their advantages and disadvantages for future benefit.

\section{دور المهنس المعماري في تصميم الكباري كعنصر جمالي و تنموي بداخل المدينة \\ مجدى محمد قاسم أحمد}

أستاذ مساعد بكلية الهندسة ـ قسم الهندسة المعمارية - جامعة الأزهر

:-1 1/لملخص

تعتبر الكبارى و التقاطعات العلوية بأنو اعها من المنشآت ذات الأهمية الكبري في التشكيل العمر اني و المعماري بداخل و خارج

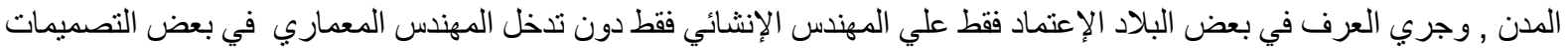

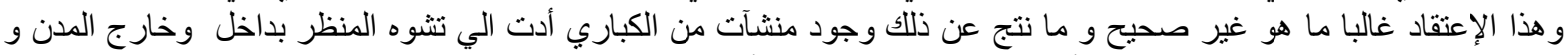

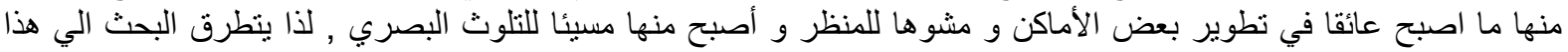

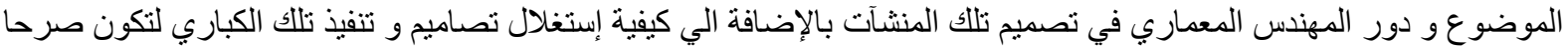

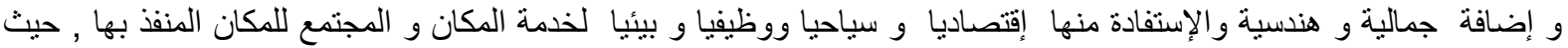

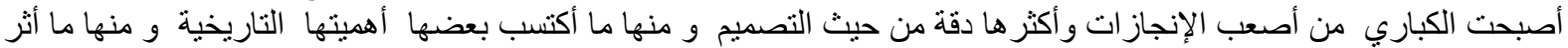

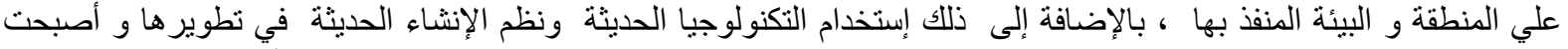

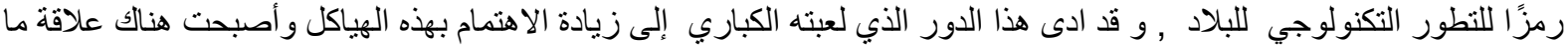

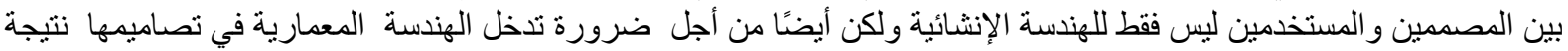

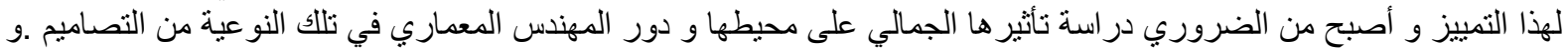

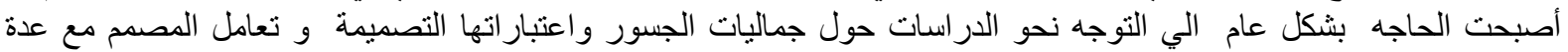

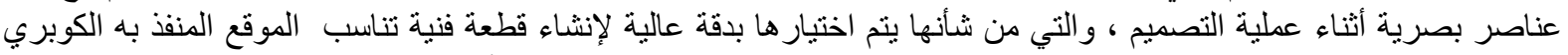

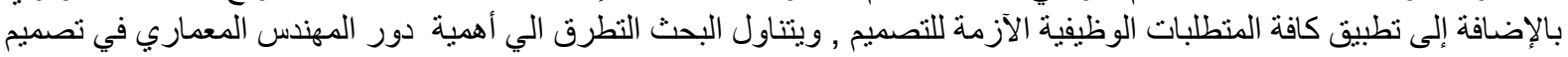

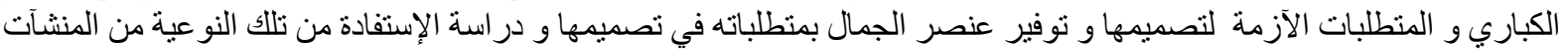

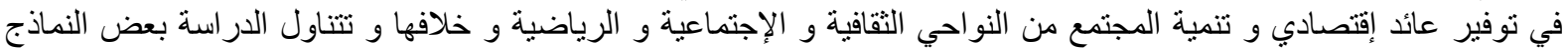

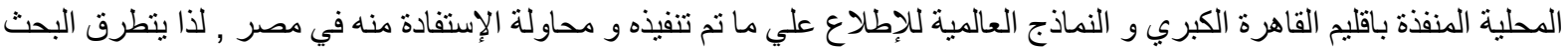
الي النظر الي تجربة تللك الكباري المنفذة و توضيح إيجابياتها و سلبياتها للإستفادة المستقبلية بالقدر المميز لها.

2- المشكلة البحثية : تمر مصر حاليا بطفرة كبيرة في تنفيذ العديد من الطرق و الكباري الجديدة لحل مشكلة التكس المروري

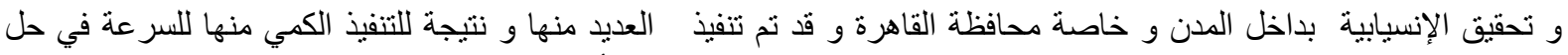

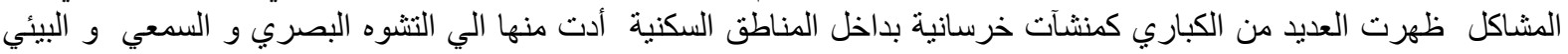

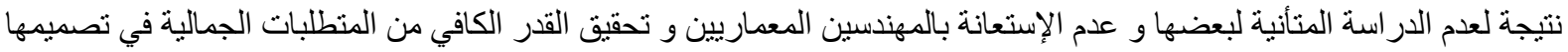

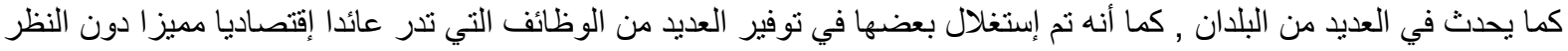

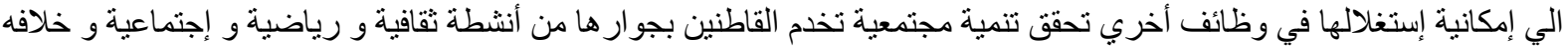

3-فرضيات الاراسةة:ان تخطيط وتصميم معظم الكباري المعاصرة في مصرناتج عن مفهوم تصميمها الإنشائي على اعتبار أنه

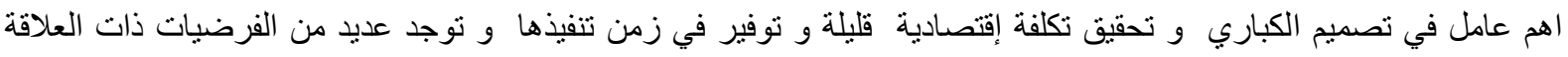

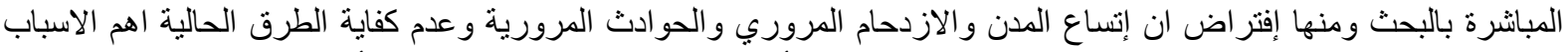

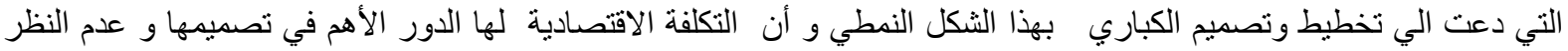

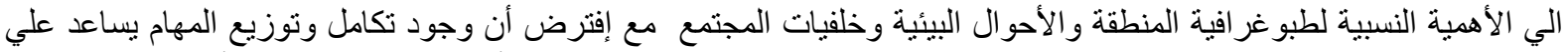

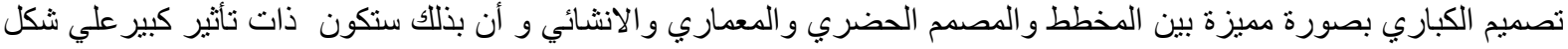

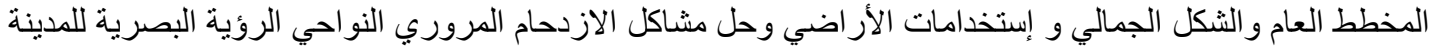

4- أنواع الكباري :- يمكن تصنيف الجسور بالنظر الى عدة جوانب منها على سبيل المثال:

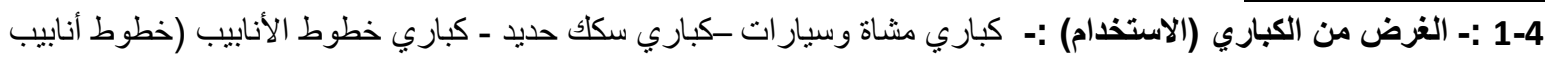
بترول - مياه - صرف صحي)-كباري مؤقتتة وغير هاريا... 


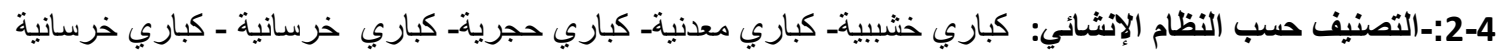

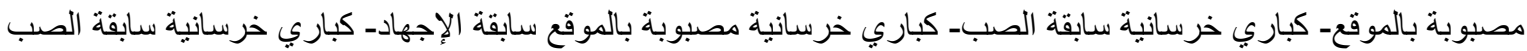

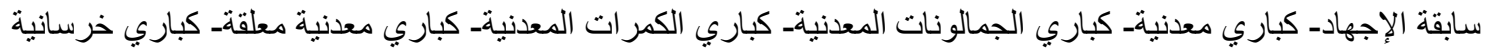
ومعدنية- كباري خرسانية معلقة.
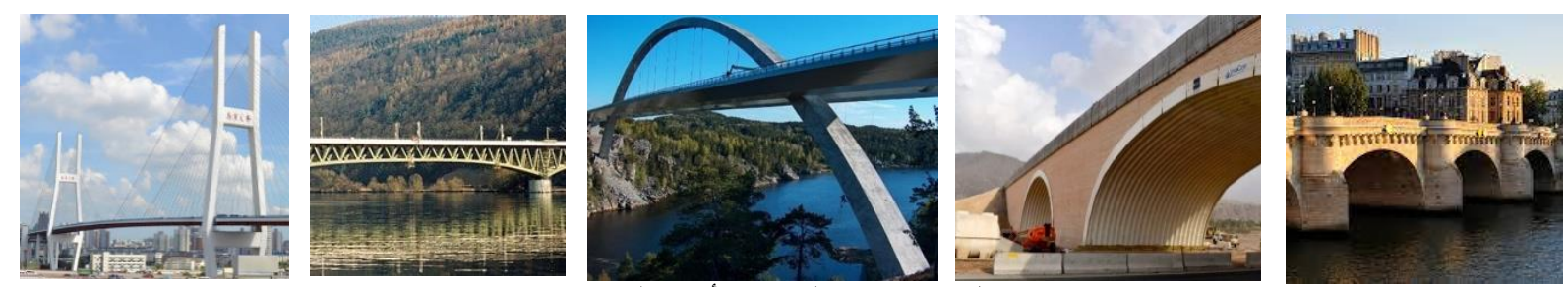

شكل (1) يوضح العديد من أنواع الكباري

5-مفهوم التخطيط والتصميم الحضري للكباري :بعتبر مفهوم تخطيط وتصميم الكباري جزء لا لا يتجز أ من تخطبط المدن،

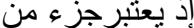

شُبكة الطرق الحضرية التي تعتبر من المكونات الأساسية للنسيج العمر اني للمدينة الحضرية للأسباب التالية :

ـ تعتبر من أهم المحددات المتحكمة في مو اقع النشاطات الإنسانية التي تعتمد عادة على تكلفة الوصول إليها.

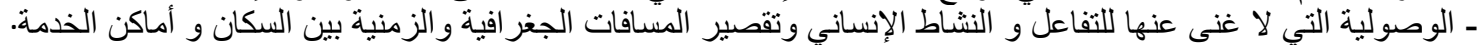

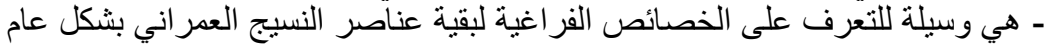

وتخطيط الطرق و الكباري الحضرية هو نوع من التخطيط القطاعي، حيث ينت من خلالها إعداد مخططات لثبكات الثبات الطرق الحضرية داخل المدينة تبين مسار ات الحركة و التنقل في المدينة ومو اقع الكباري ، ويتم ذلك من خلال در اسات تحليلية لثبكة الطرق

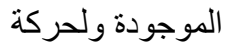

المرور عليها وخصائصها ومن ثم دراسة توقعات حركة المرور وخصائصها المستقبلية.

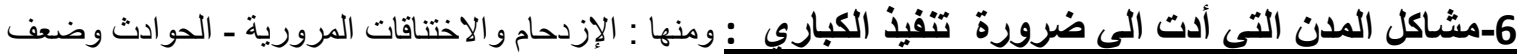

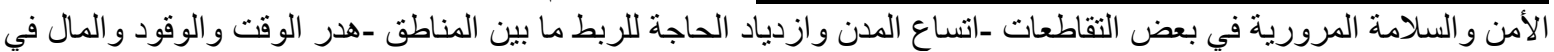

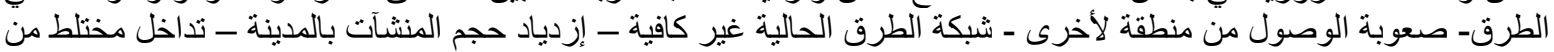

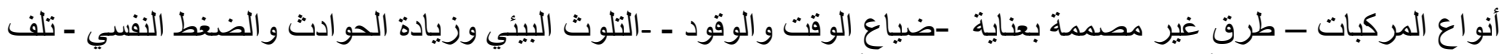

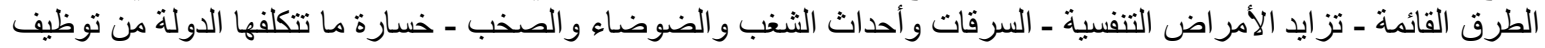

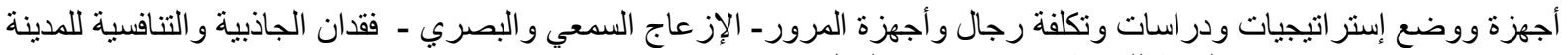
- مقدان بعض الاقتصاديات الهامة للمدينة ـ فقدان فرص الت العمل

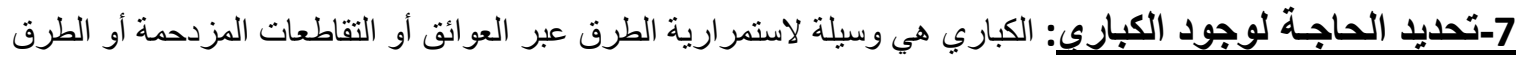

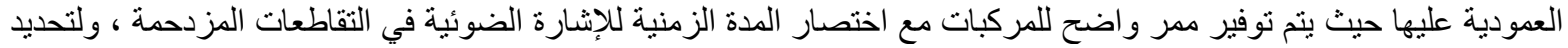

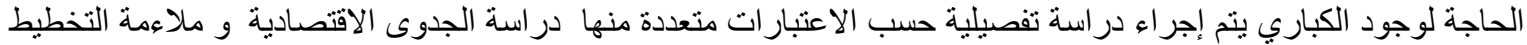

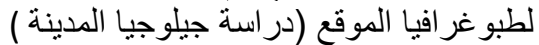

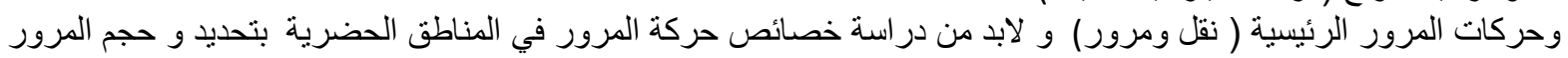

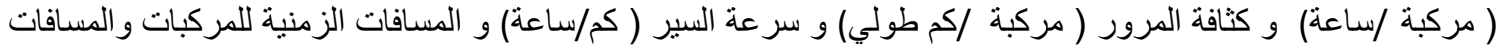
الفراغية بين المركبات

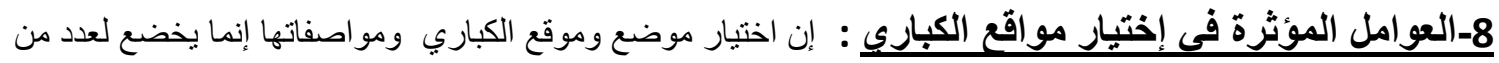

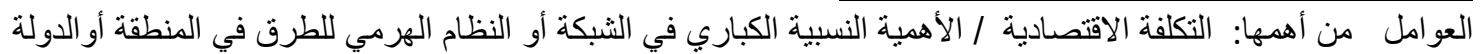

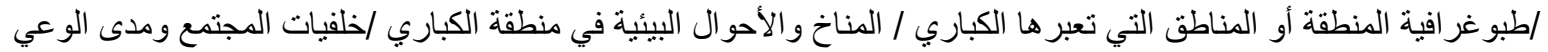
و والتجاوب مع المو اصفات.

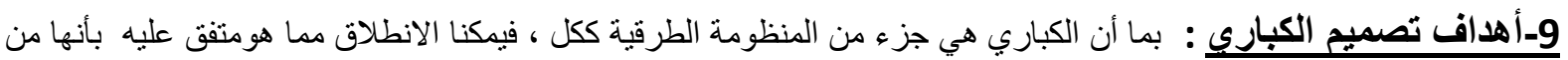

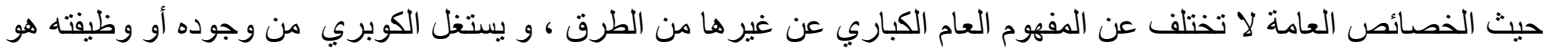

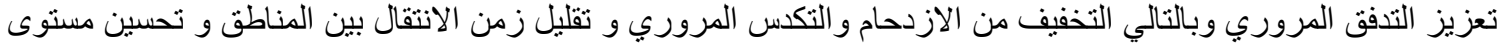

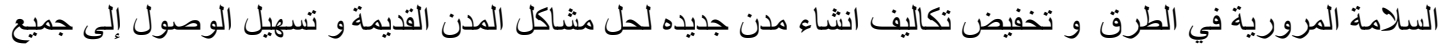

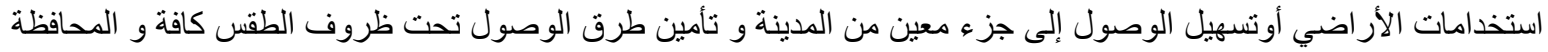

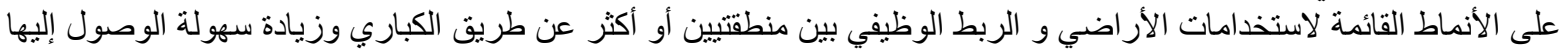

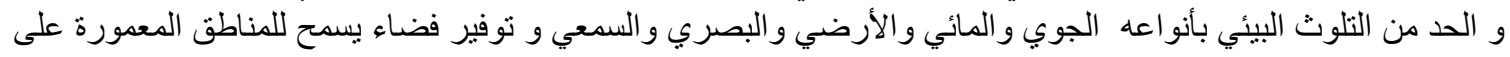




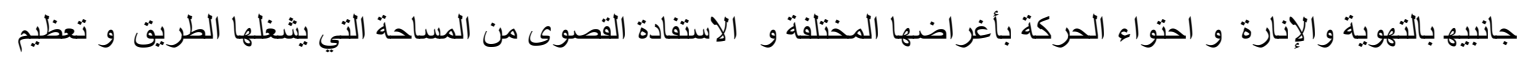

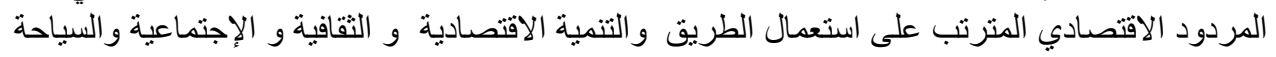

\section{0-إجزاءات عملية تصميم الكباري:}

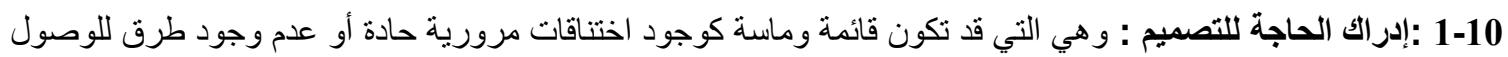

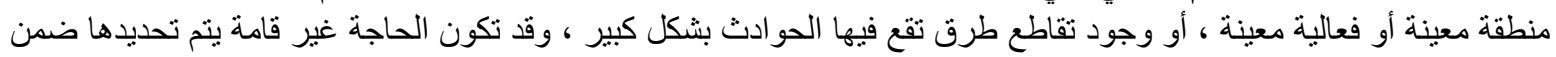

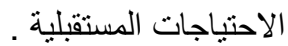

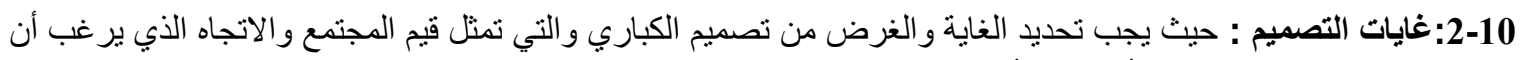

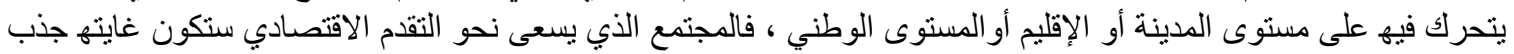

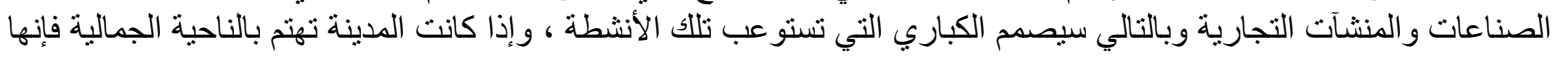

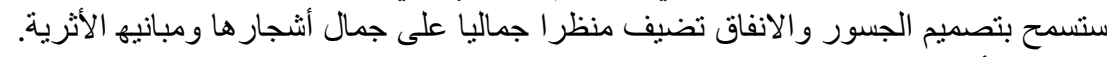

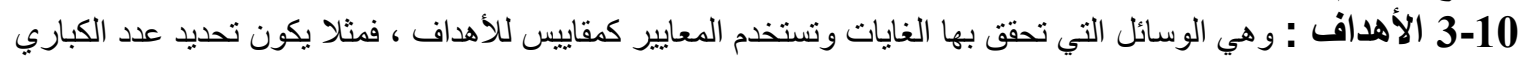

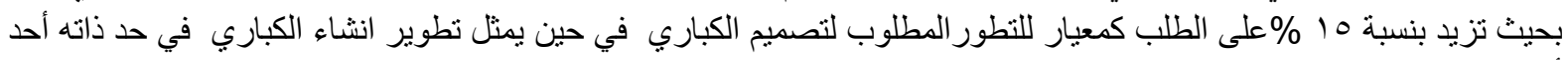

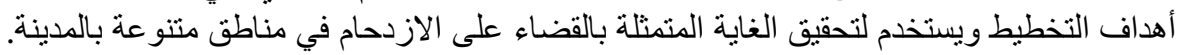

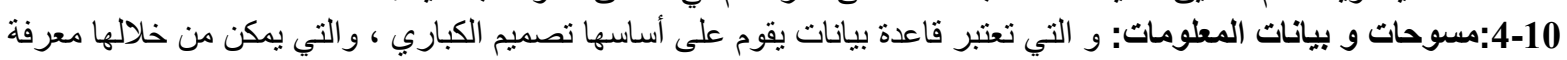

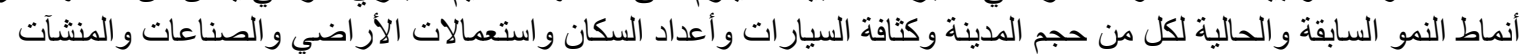
التجارية.

5-10:تحليل الطلب : الذي بموجبه يتم توزيع مو اقع الكباري على المدينة ، كما تتم مقارنة السعة القائمة بالطلب القائم وتحديد

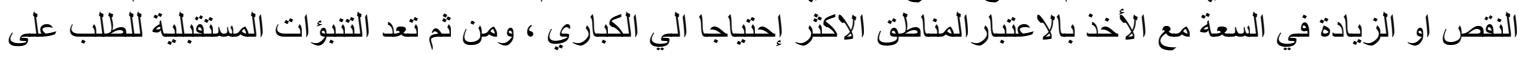
زياده اعداد الكباري

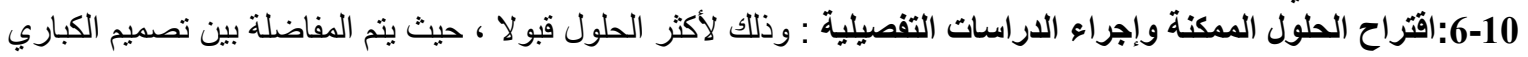

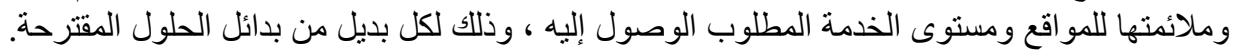

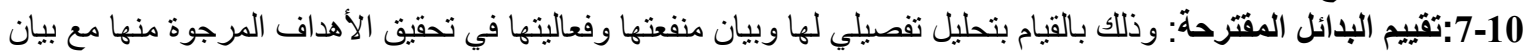

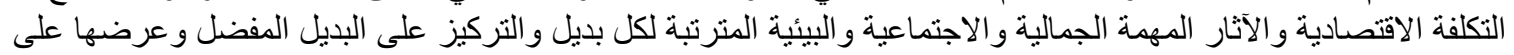

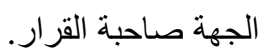

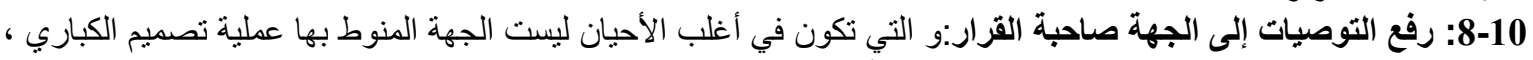

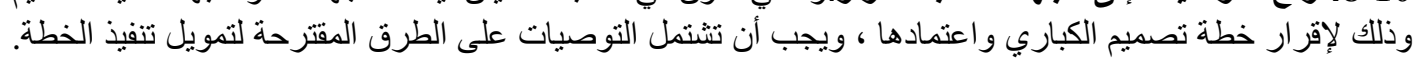

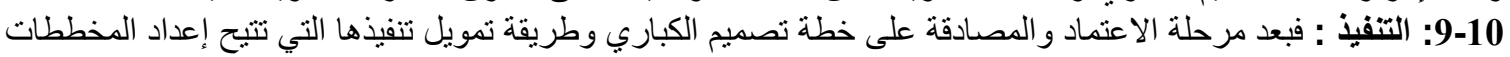

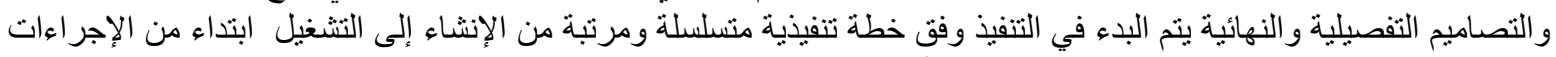

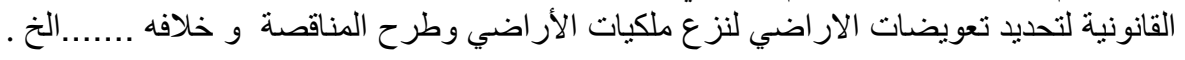

11:أسس تصميم الكباري في المناطق الحضرية: ينتم تخطيط و تصميم الكباري وفقا لمر احل وخطوات وات ومنها خطط

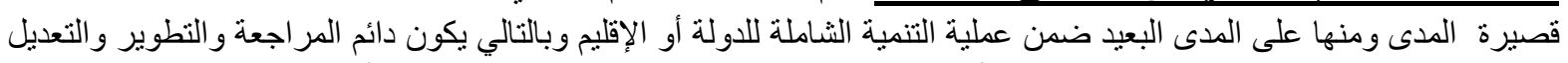

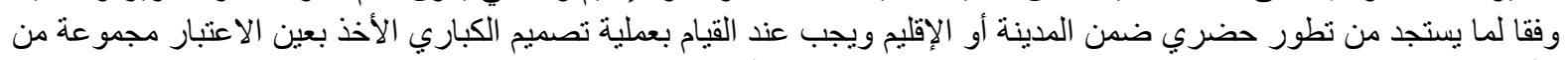

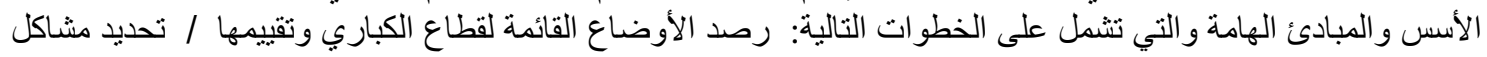

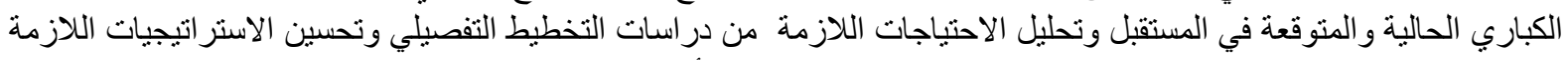

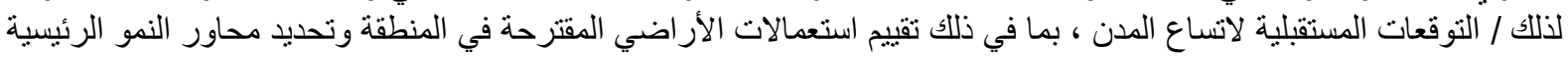

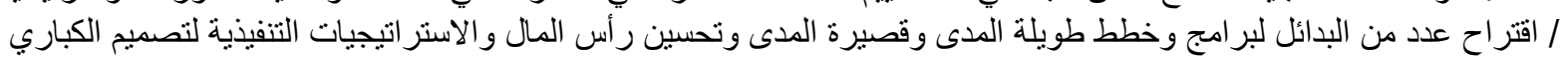

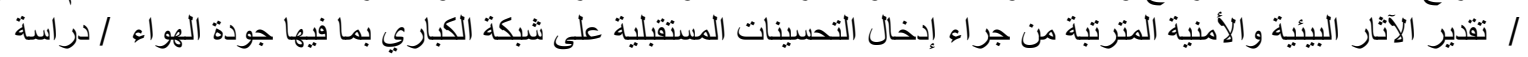

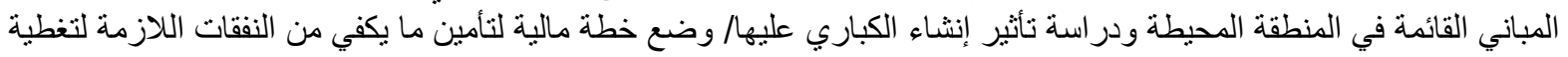
تكاليف تنفيذ الاسنر اتيجيات.

12:مبادئ تصميم الكباري في المناطق الحضرية: تستند المعايير والإرشادات على مبادئ التصميم الأساسية التي تسهم

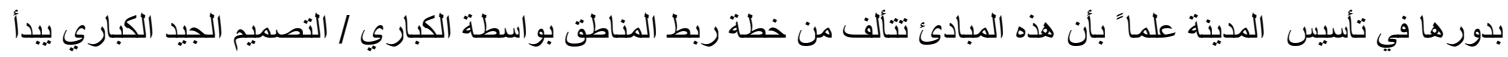

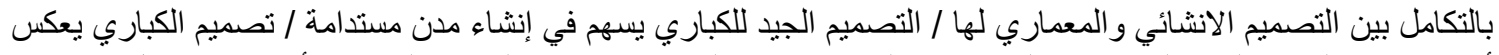

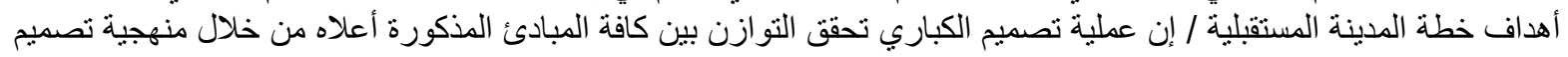
متكاملة

13:مصادر مشاكل الكباري: تشثير الدراسات إلى أن هناك الكثير من المشاكل التي تعاني منها الددن و الدجتمعات من جراء

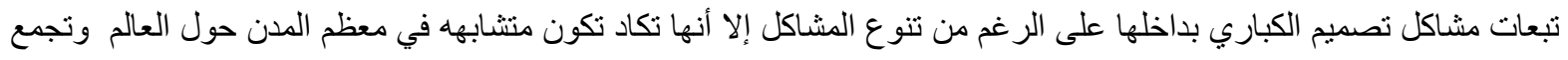


الغالبية على أن عدم كفايتها لحل مشاكل الازدحام بالاضافة الي عدم الاتمام بتأثير تصميمها علي شكل المدينة هي أكبر تلك

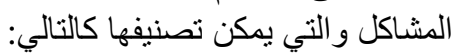

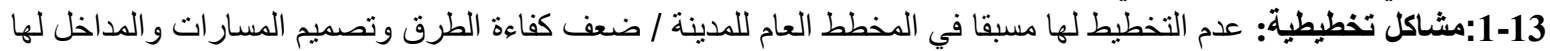

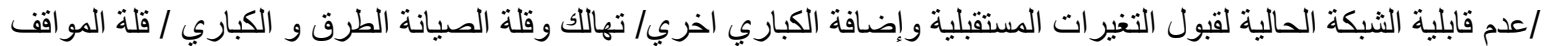

وسوء تنظيمها.

2-13: غياب دور المهندس المعماري: حيث يمثل ذلك قصور في التصميم الهندسي الكباري و البيئة العامة الكباري و الناحية الجمالية لهاو عدم تصميم مناسب للأنثطة الوظيفية المكملة لها ( تقافية - إقتصادية - .........

2-13:مشاكل إدارية:عدم وجود إستر اتيجيات أو سياسات ونظام متكامل للخطط المستقبلية لأنثاء الكباري / ضعف التبات التسيق بين

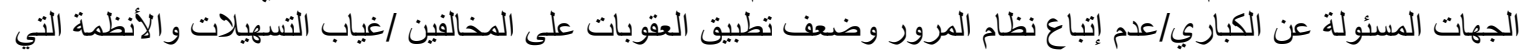

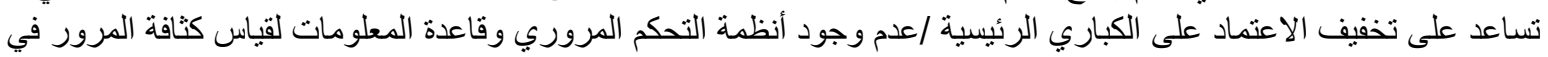

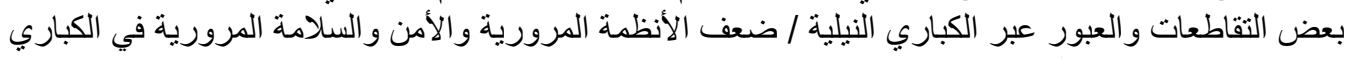

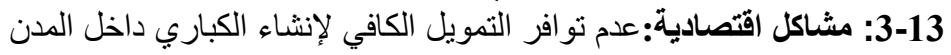

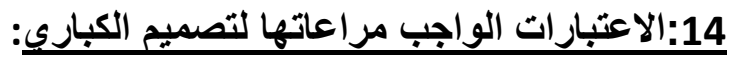

1-14:شكل الجسر: من التخطيط الأفقي و الرأسي للكوبري ـ القطاعيات الإنشائية المسموح بها للكوبري (العمق ـ عرض الدعامة

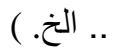
ـ دراسة حركة المرور أثناء تنفيذ الكباري ـالخدمات الرئيسية ـالتكلفة التقديرية للكوبري ـ طبيعة التربة عند موقع الكباري ـالزمن

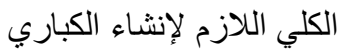
2-14-3 :تفاصيل التنفيذ : من طريقة التتفيذ ـ مو اد الإنشاء ـ معدات الإنشاء.. إلخ.

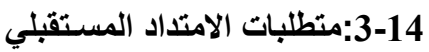

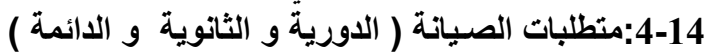

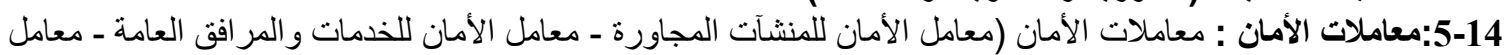

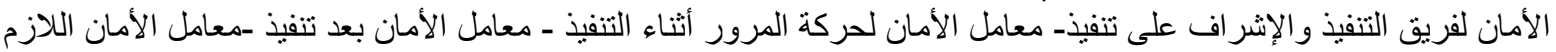

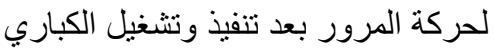

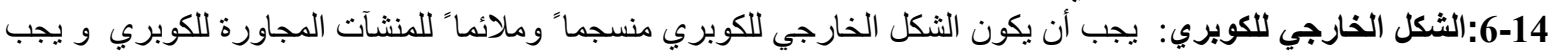

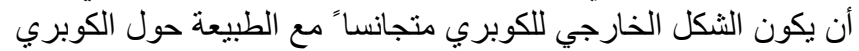

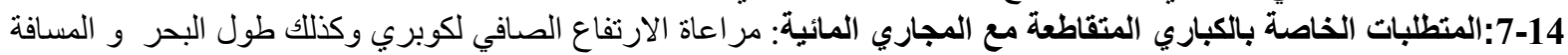

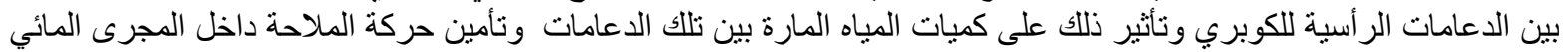

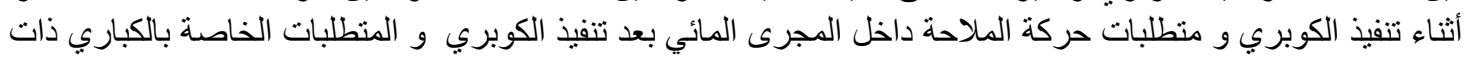

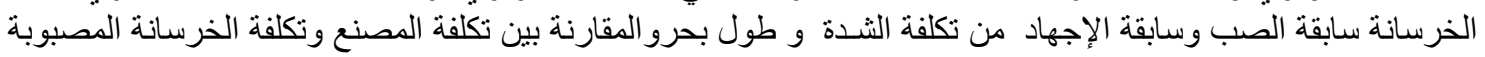

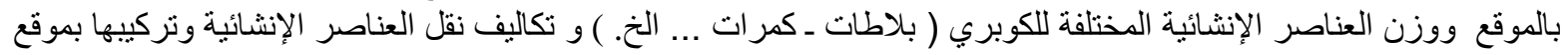

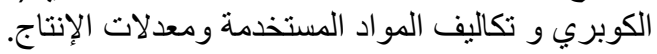

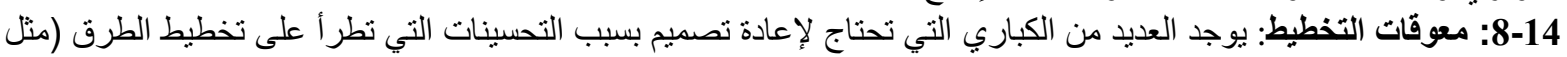

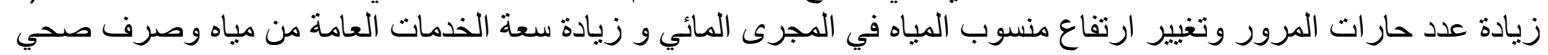

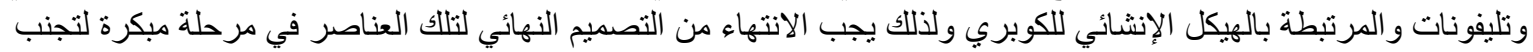
زيادة تكاليف إنثاء الكوبري وكنللك زيادة الزمن اللازم لاعادة التصميم

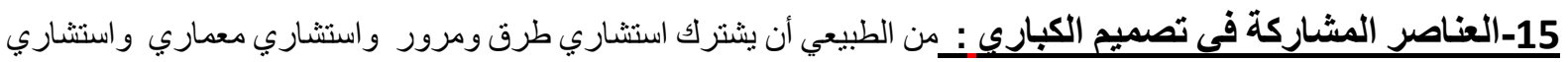

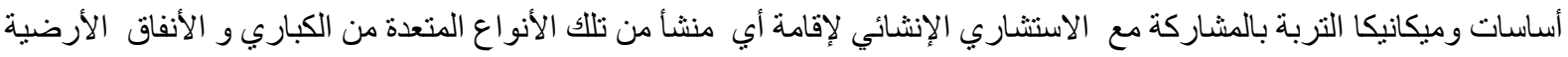
16-الأعتبار ات العامه الواجب مراعاتها عند التخطيط الأولى للكباري: تعتمد الإعتبار ات التي يجب مر اعاتها عند تصميم

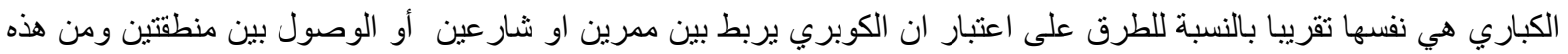

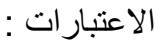
مدى الكثافة و الحركة المرورية القصوي والسر عة التصميمية للثو ارع وحجم مرور المركبات بأنو اعها ــ تحديد ازدياد النمو وحركة

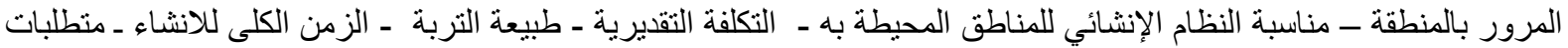

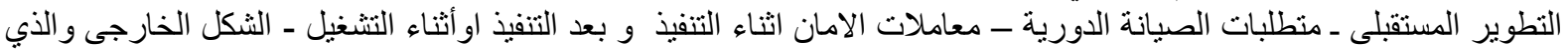

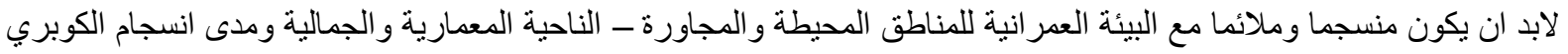

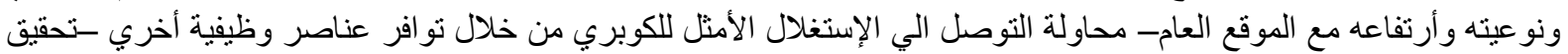

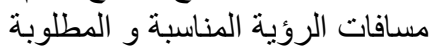

17- البيانات الأولية لتصميم أعمال الكباري:هناك حاجة إلى قدر كبير من البيانات في بداية أعمال تصميم الكباري ومنها : 
ـ مخطط للموقع يوضح جميع العو ائق التي يجب مر اعتها مثل الأنهار و الثوارع و الطرق و السكك الحديدية و الخطوط الكنتورية

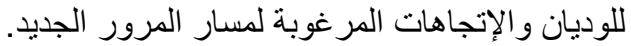

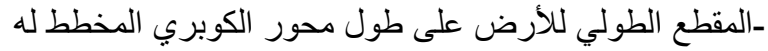

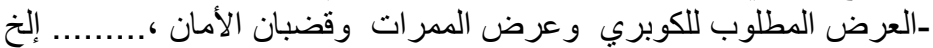

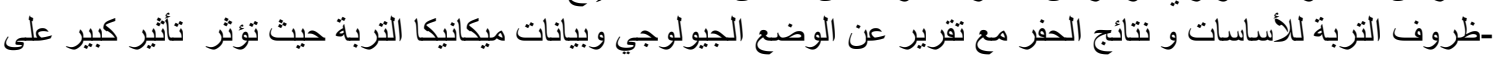

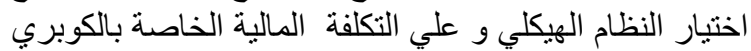

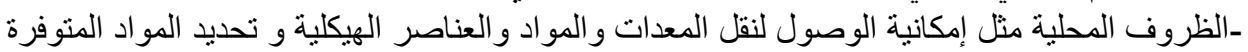

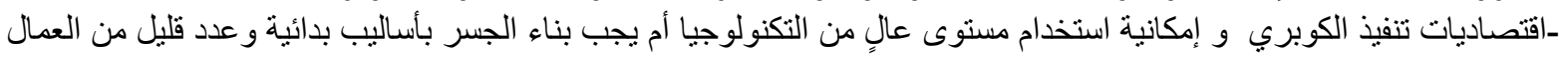
المهرة - الظروف و التضاريس البيئية و المناخية المحيطة بالكوبري

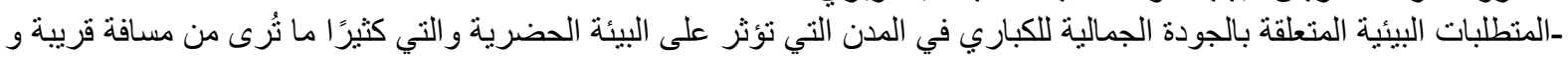

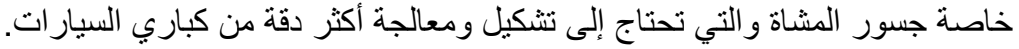

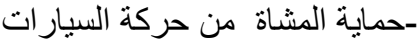

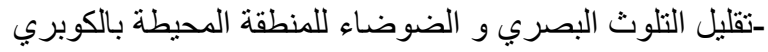
18:المظاهر الجمالية للكباري : لابد أن تكمن أهمية معظم الكباري بمظهر ها، ولكن في بعض الكبري الحالات، يكون حتى لمظهر

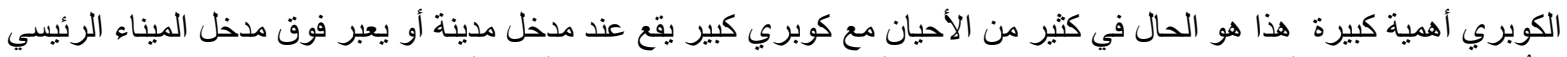

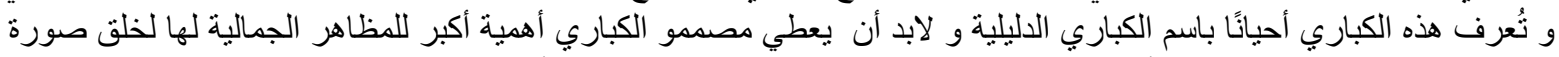

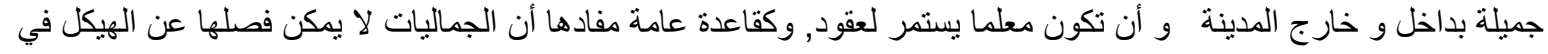
تصميم الكوبري .

19: مفهوم الجمال في الكباري : تعتبر جماليات الكباري هي تلك المنشآت التي تؤدي وظيفتها في اجتياز العوائق بكفاءة

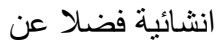

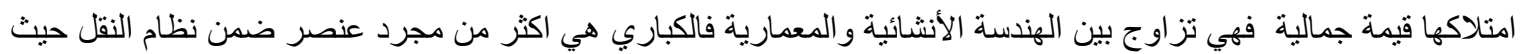

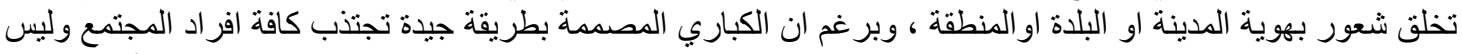

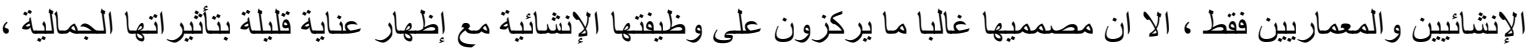

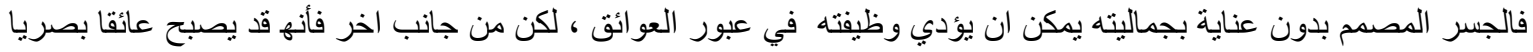

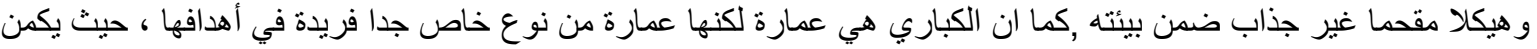

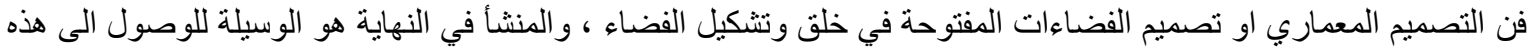

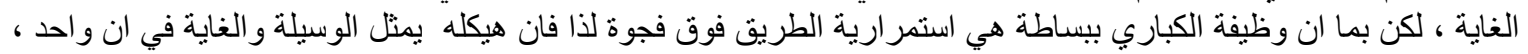
وحقيقته لا تكمن في تطو يق الفضاء لكن في المنشأ نفسه.

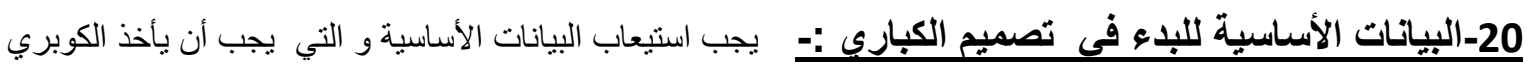

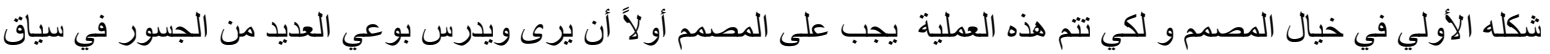

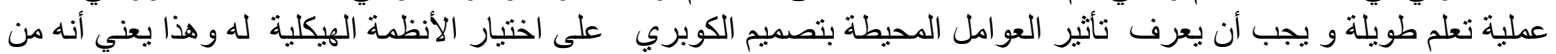

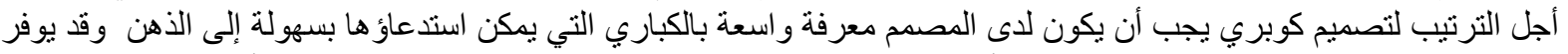

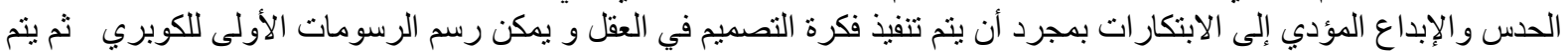

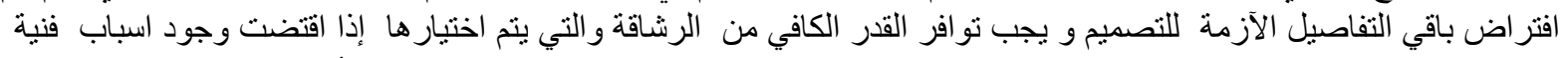

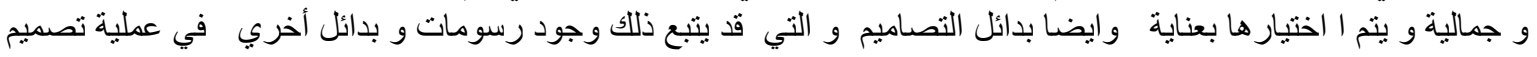
الكباري و التي تتم مر احلها كالتالي :

1-20:-اطلاع المختصين والمهتمين على الإسكتشات الأولية :و هذا يشجع على انتقاد الزملاء و لا سيما تعليقات أولئك الكئ

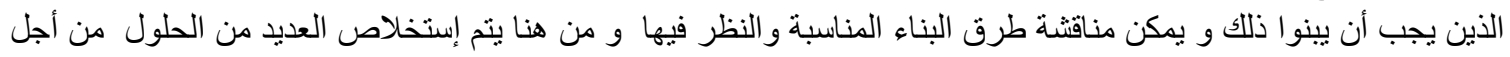
تحسين التصصميم والاستفادة من الخبرة المكتسبة من التصميمات السابقة التئية نم تحقيقها.

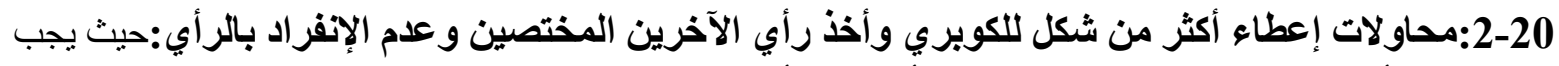

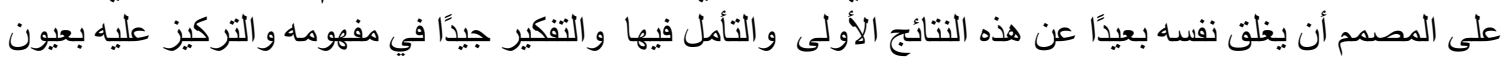

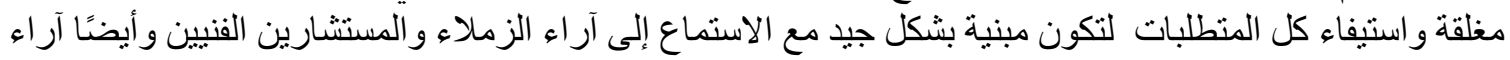
الأشخاص العاديين

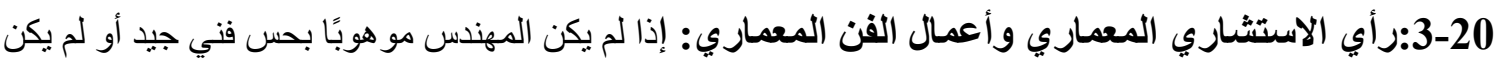

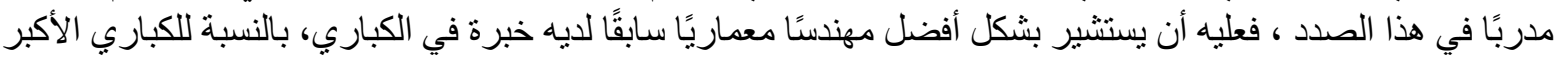




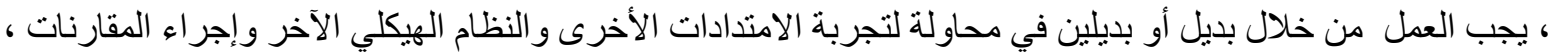

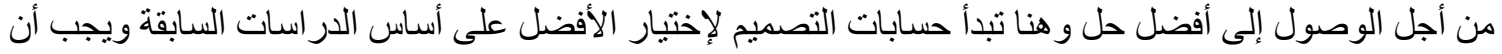

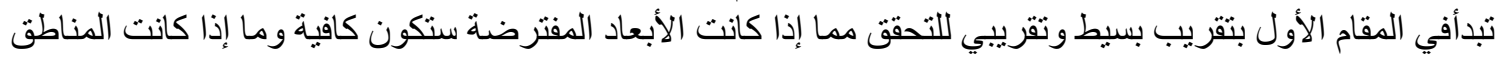

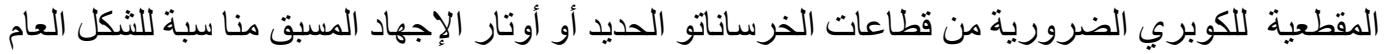

أعماي 4-20:ضرورة الاستعانة بأجهزة الحاسب الآلي: يمكن إجراء بعض العمليات باستخدام مبرمجي الكبيوتر وباستخدام

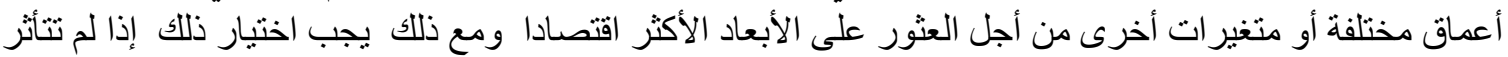

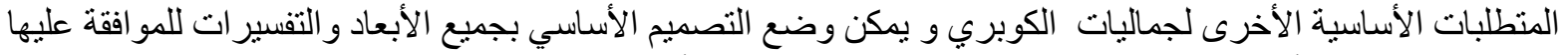

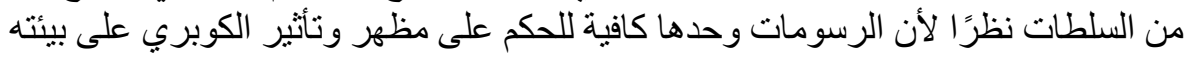

5-20:اجراعات ا لتصميم النهائي : بعد المو افقة على التصميم يمكن أن تبدأ أعمال التصميم النهائية بحسابات دقيقة

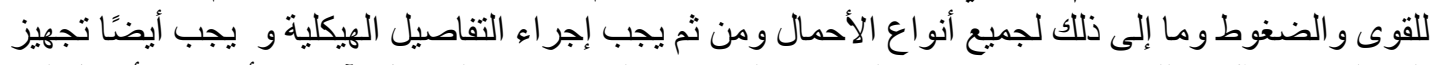

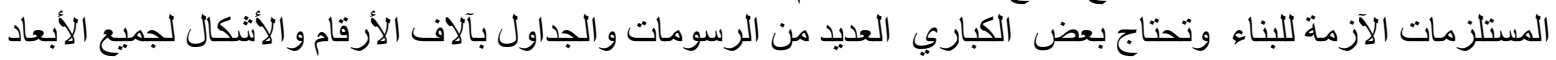

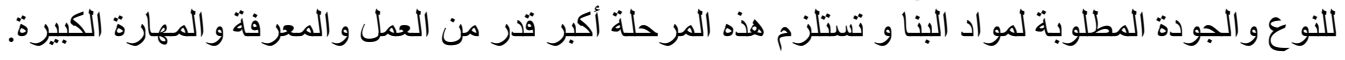

21- الثكل الجمالى للكباري و مشاركة المعماريين في تصميمها : على مر التاريخ كان الناس ينشئون كباري بقدرة

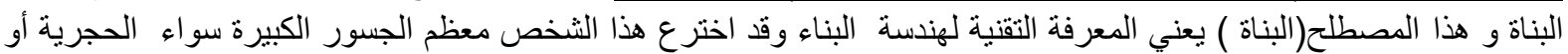

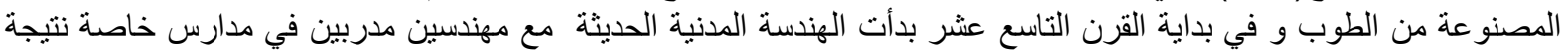

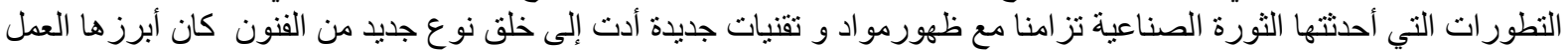

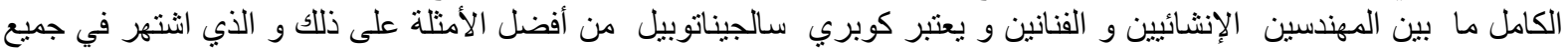

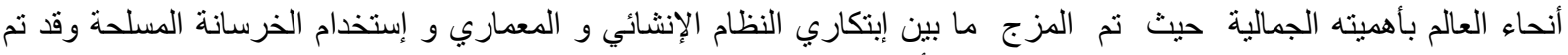

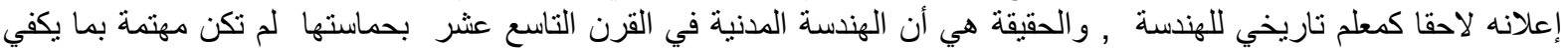

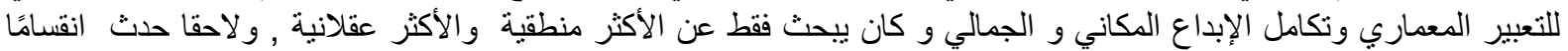

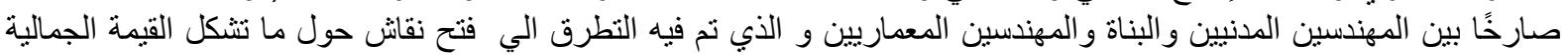

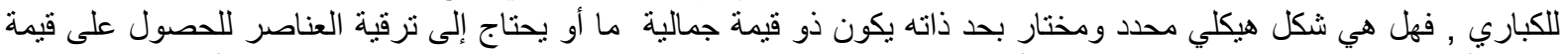

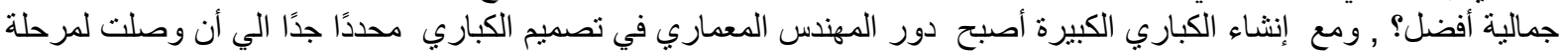

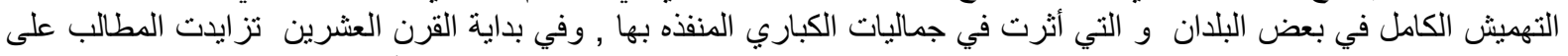

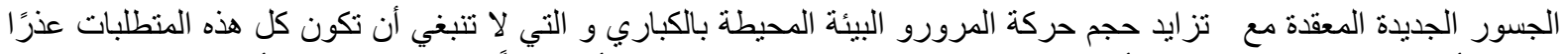

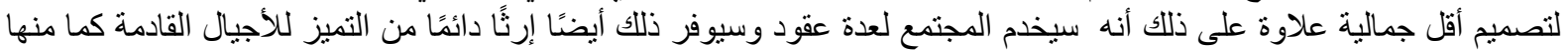

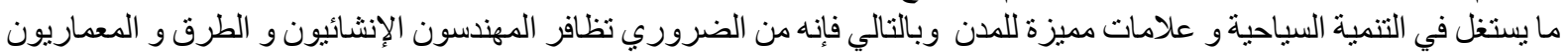

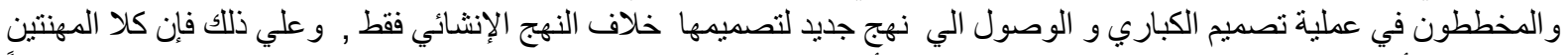

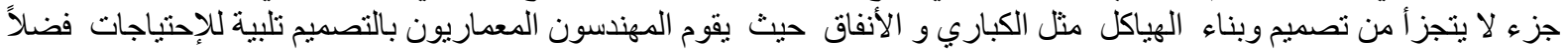

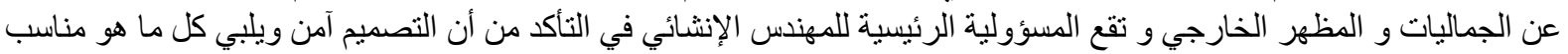
عن طريق إختيار المو اد الإنشائية وتحديد العناصر الإنشائية المناسبة للتصميم والبناء مع إستخدام التكنولوجيا الآزمة التانية في توصيل

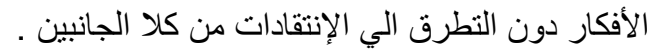

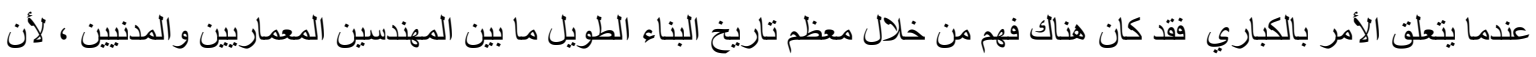

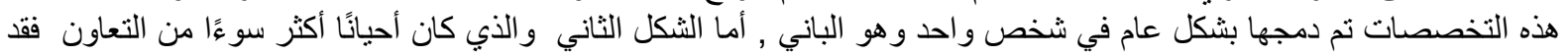

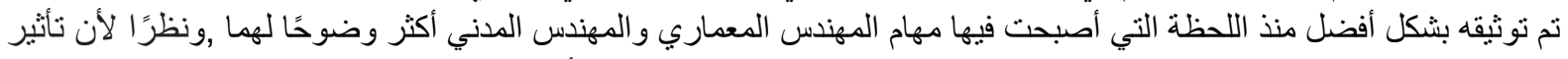

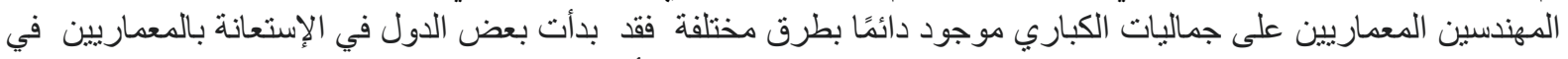

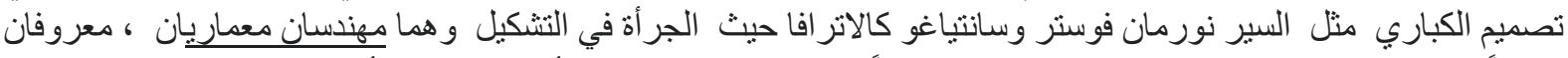

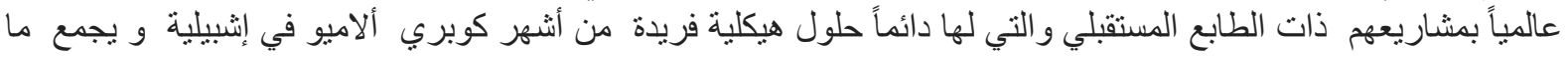

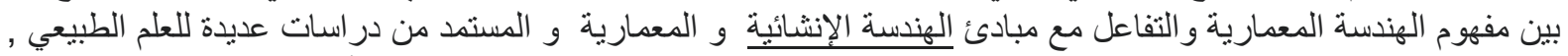

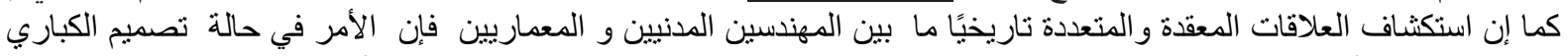

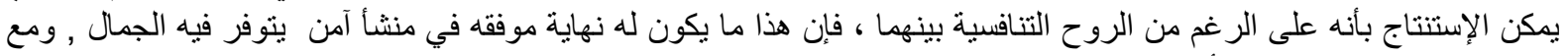

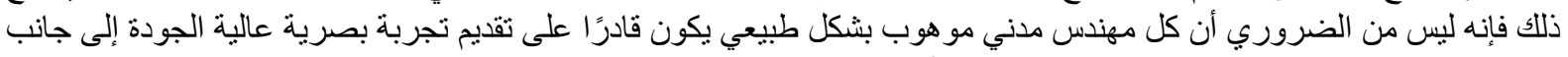
وظيفة جيدة الحل ، ولا يستطيع كل مهندس معماري أن يشعر بحركة القوى و الآمان من خلانل هيكل ميكل الكوبري 

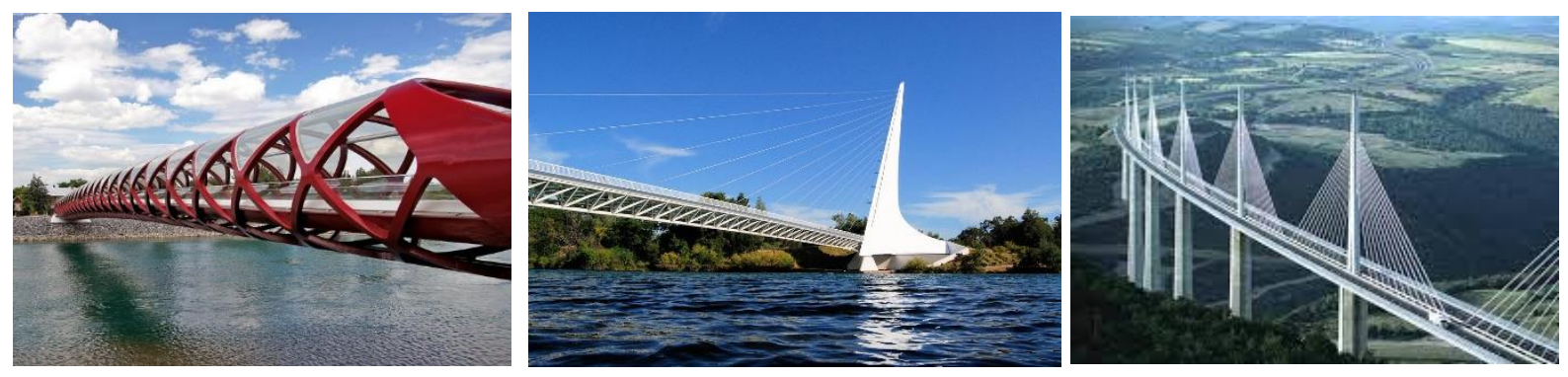

شكل (3) كوبري الاميلو و كوبري كالجاري للمعماري سانتياغو كالاترافا

شكل (2) كوبري ميلو للمعماري نورمن فوستر

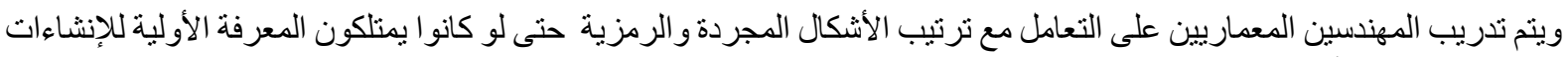

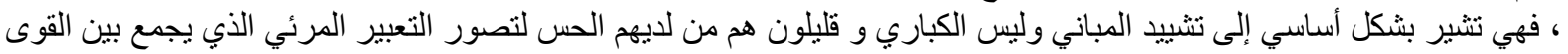

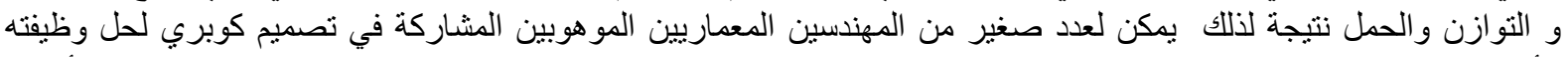

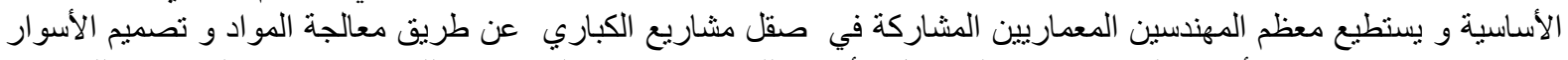

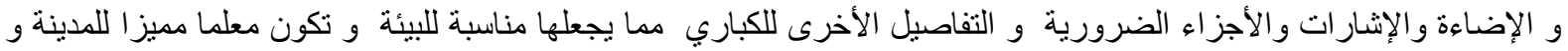

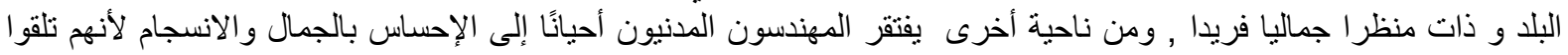

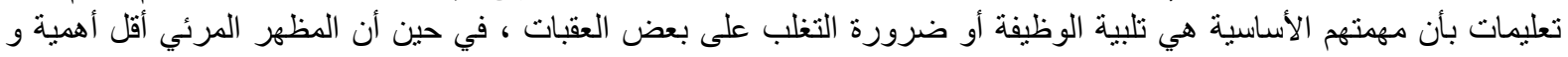
الأشكال من (4 الي 15 ) لمشاريع تصاميم كباري من تصميم معماريون عالميين.
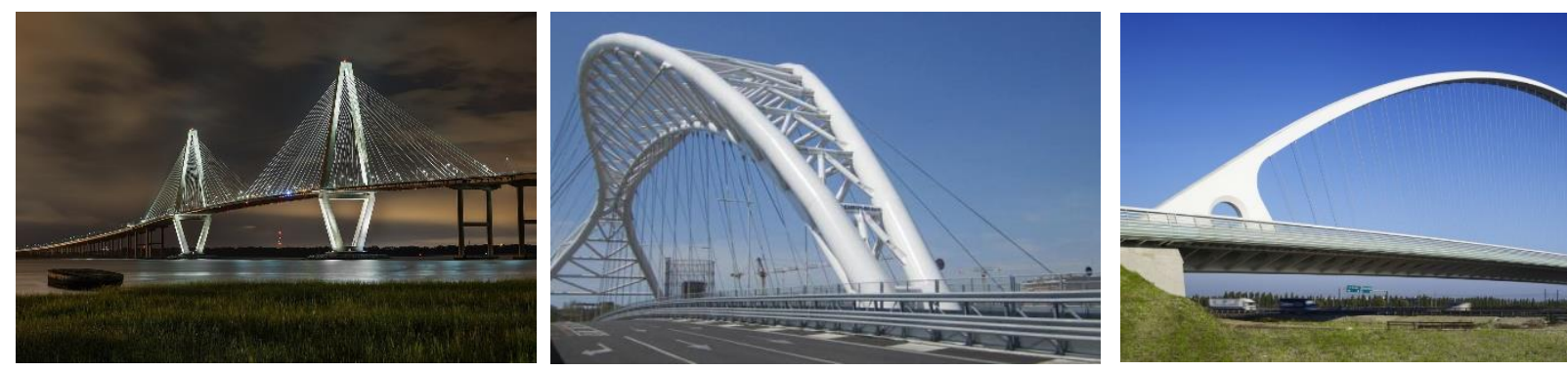

شكل (4) كوبري ريجو ايميلا بإيطاليا للمعماري سانتياجو كلاتر افا شكل (5) كوبري بونتي ديلا ميوزيكا شكل (6) جسر رافينيل بأمريكا لمقاولي بارسونز
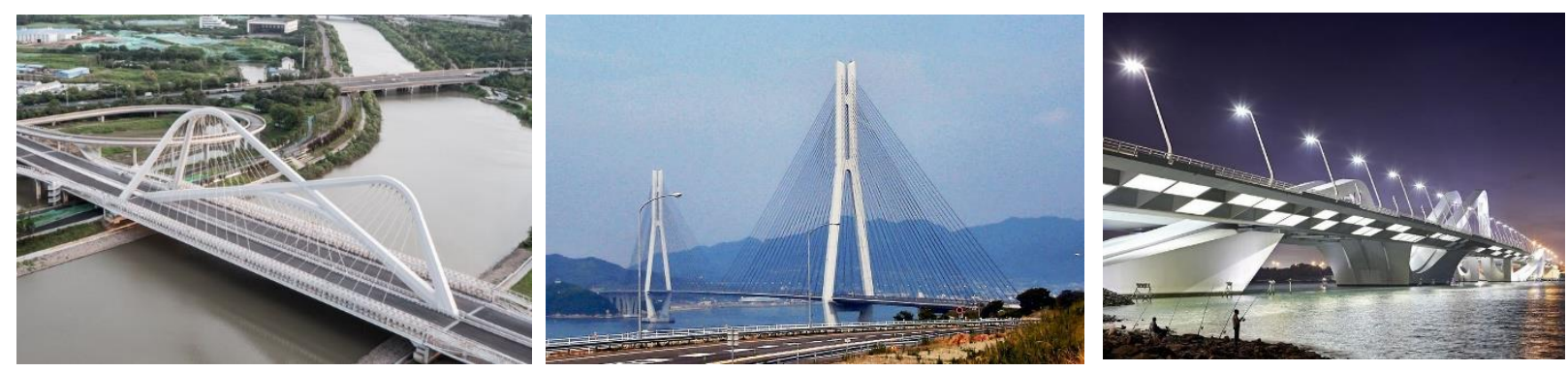

شكل (9) كوبري( دانغوج بنايوان) - نان (معماريون
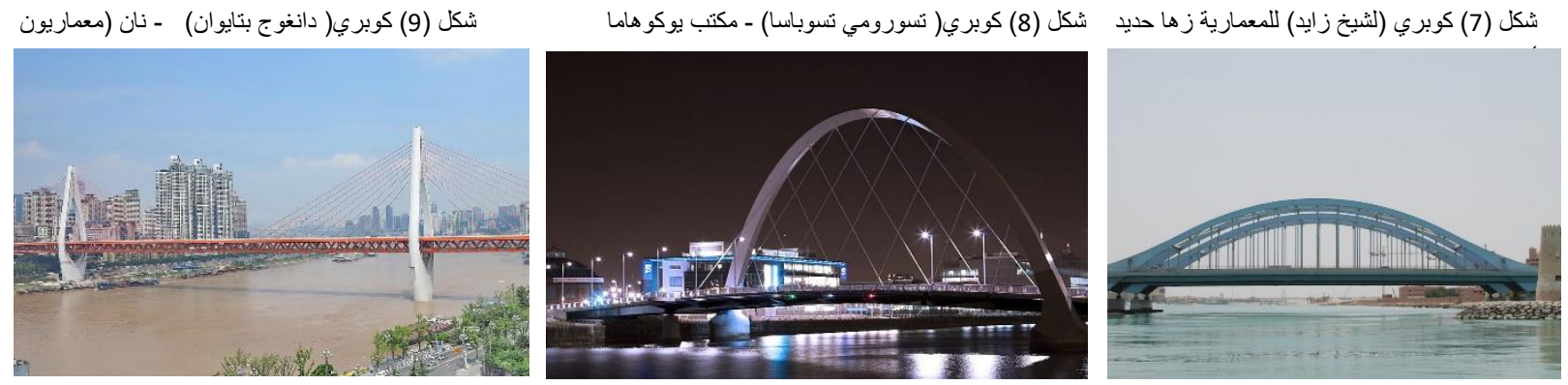

شكل (12) كوبري ( تشونغتشينغ ) - ليو شاوي

شكل (11) كوبري (كلايد ارك )- هالكراو/ غلاسكو شكل (10) كوبري (حصن المقطع) للمعمارية زها حديد 
دور المهندس المعماري في تصميم الكباري كغنصر جمالي و تنموي بداخل المدينة
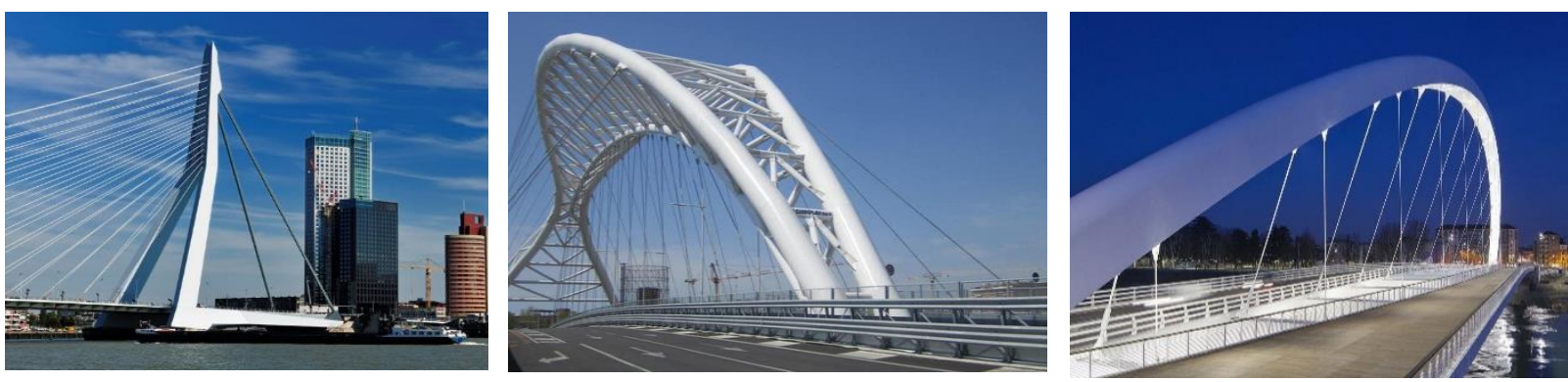

شكل (15) كوبري(اير اسموس) - بن فان

شكل (14) كوبري (بونتي ديلا ميوسكا )- بيرو هابيلد

شكل (13) كوبري (سيتاديلا )ريتثارد ماير

بركل

22:المفاهيم التطيقية لجماليات الكباري : ظهرت على مستوى العالم ثلاثة مفاهيم تطبيقية تتعامل مع تصاميم الكباري

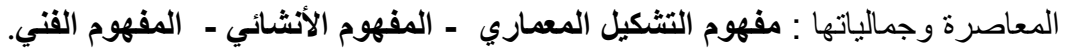

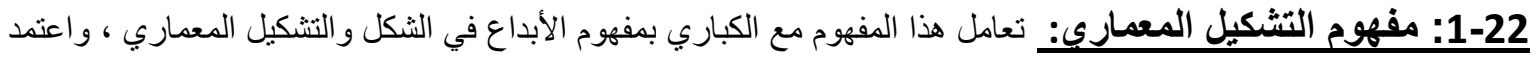

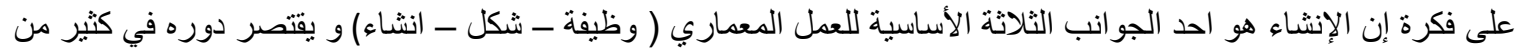

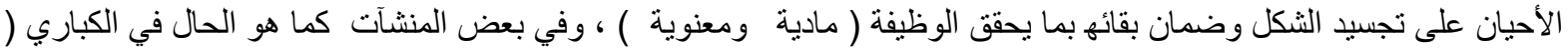

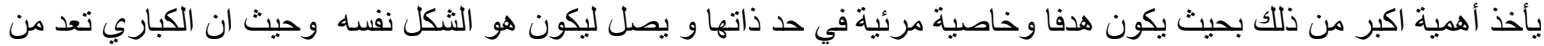

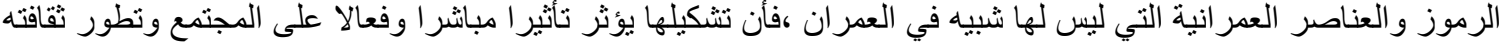

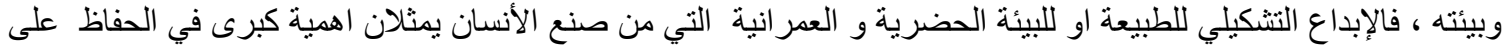

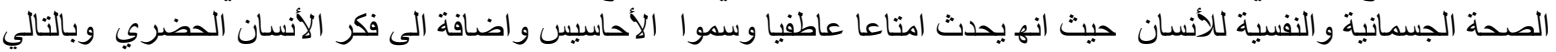

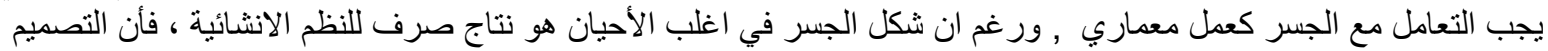

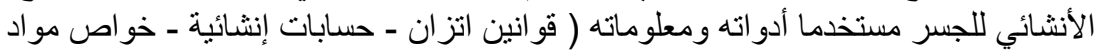

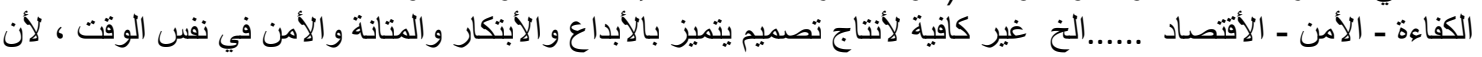

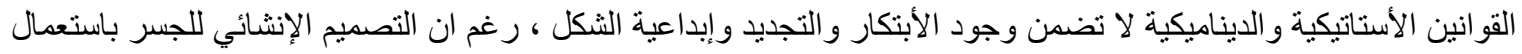

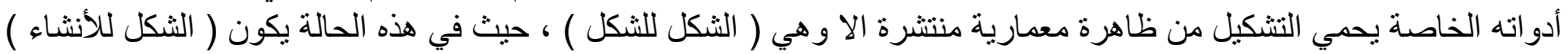

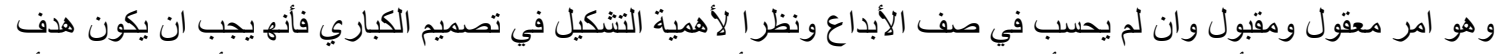

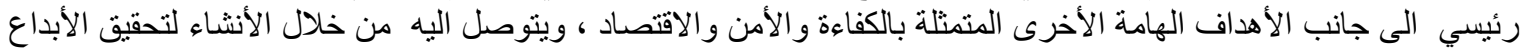

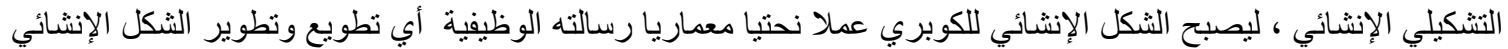

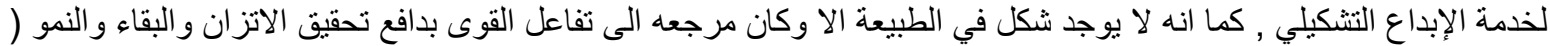

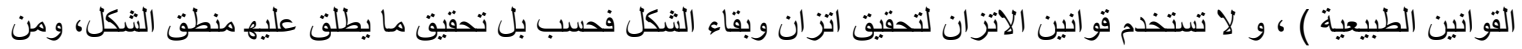
منطق الثكل ينبثق الأنفعال بالجمال.

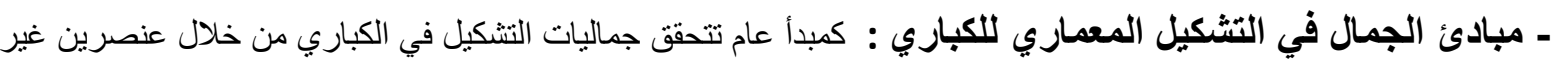

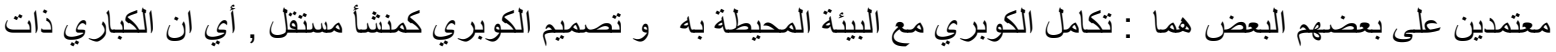

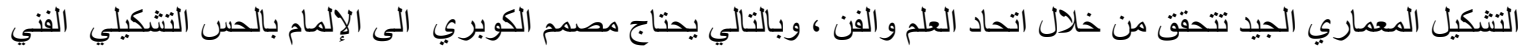
بجانب الحس الأنثائي العلمي.

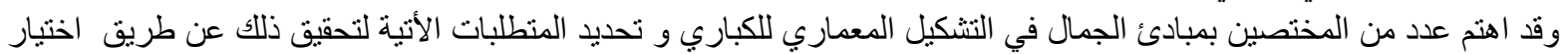

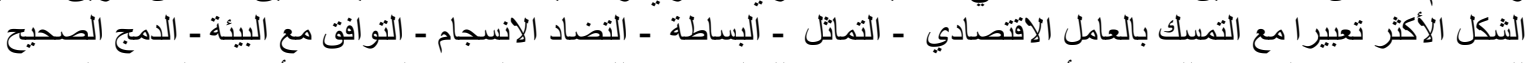

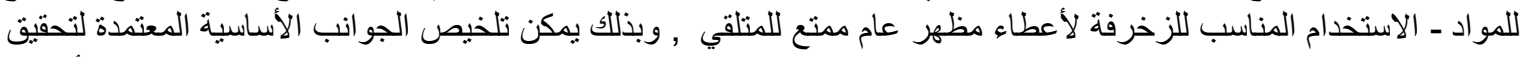

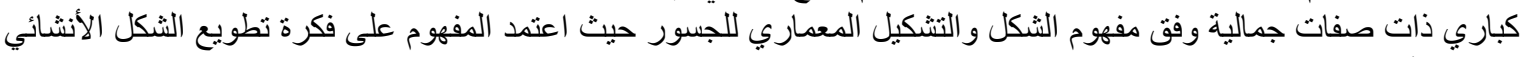

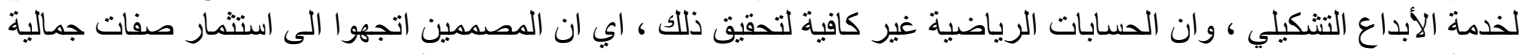
للمنشأ بعيدة عن الجمال الناتج من الحسابات الرياضية الدقيقة ) و الذي سيظهر في الذية المفهوم الأنشائي .

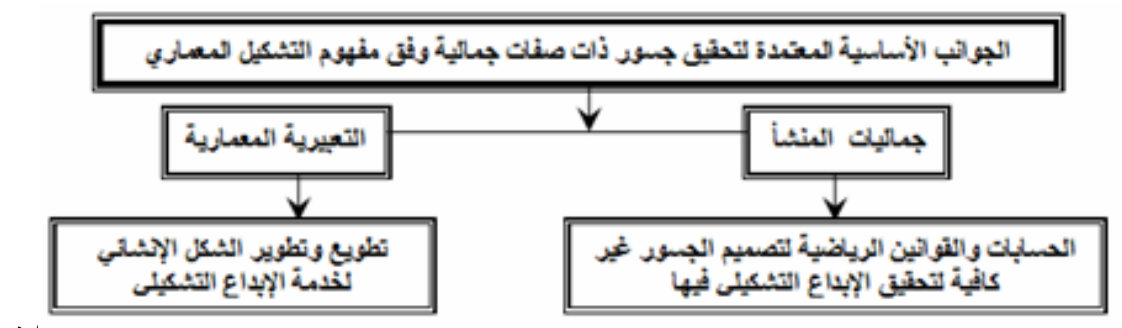

شكل (16) يوضح اهم الجوانب التي يقوم عليها مفهوم التشكيل المعماري في خلق كباري دات صفات جمالية 


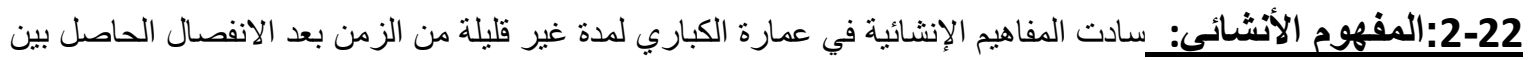

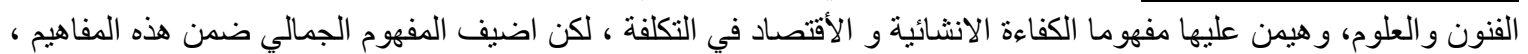

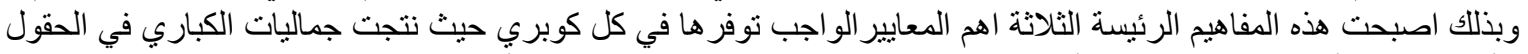

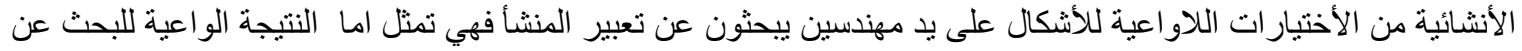

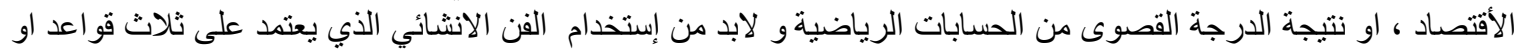

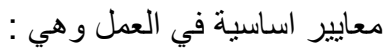

ـالكفاءة :- وتعني استخدام اقل ما يمكن من المواد مع امكانية السيطرة على توفير عامل الكائل الأمان.

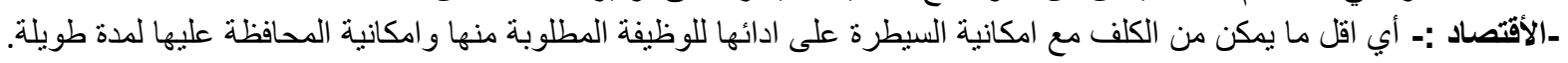

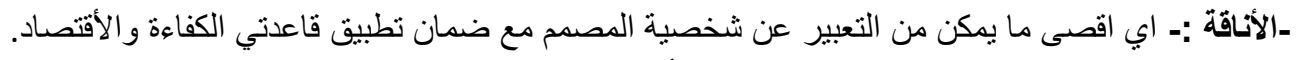

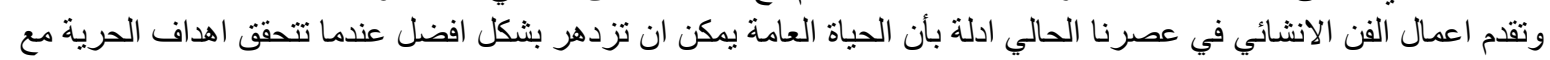

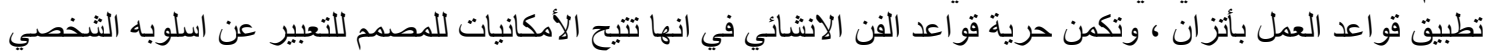

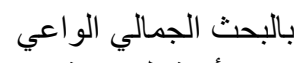
عن الأناقة الهندسية العية

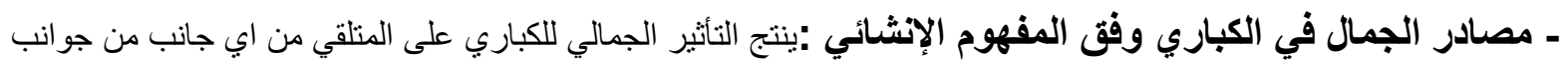

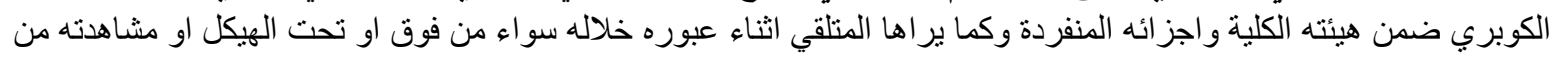

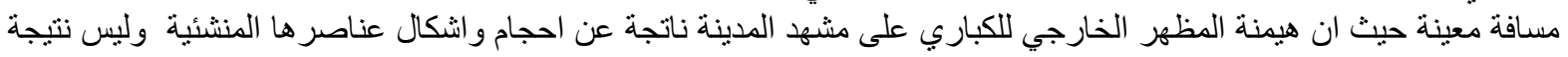

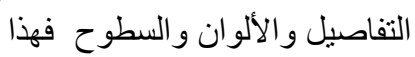
يعني أن التأثير الجمالي الأعظم ناتج عن:

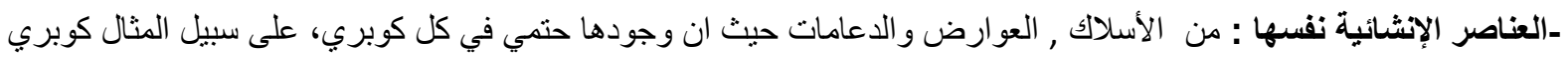

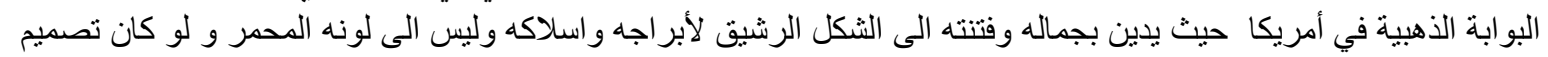

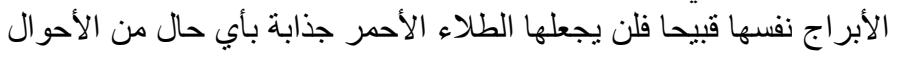

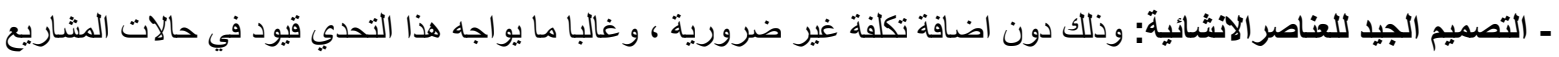

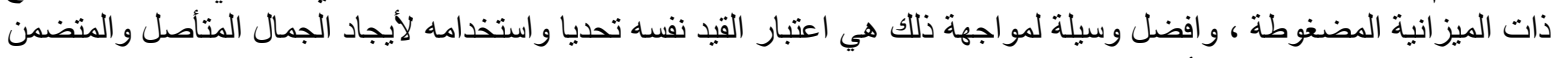

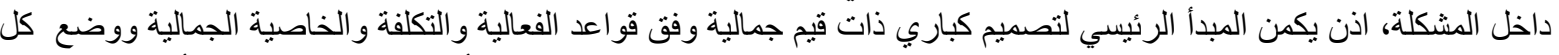

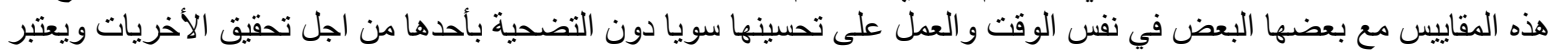

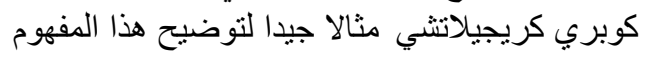

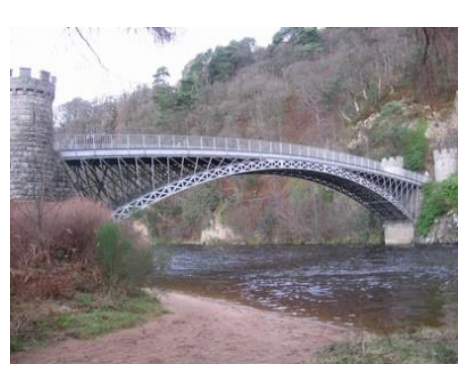

شكل (19) كوبري كريجيلاتشي

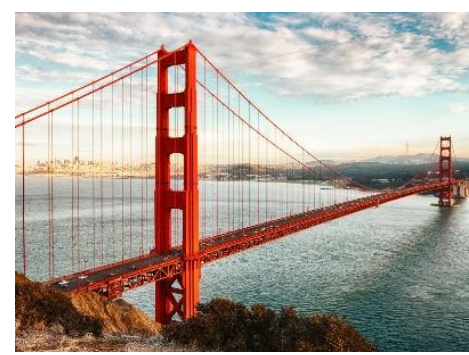

شكل (18) كوبري البوابة الذهبية

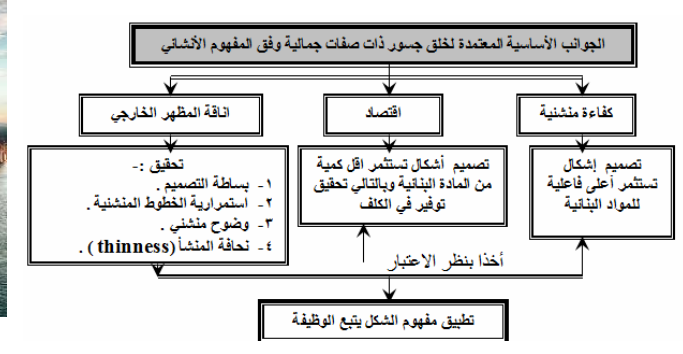

شكل (17) يوضح أهم الجوانب الأساسية في خلق كباري ذات صفات جمالية وفقا للمفهوم الإنشائي

-خصائص الكباري ذات الصفات الجمالية وفق المفهوم الأنشائي: تتنلخص خصائص الكباري ذات الصفات الجمالية

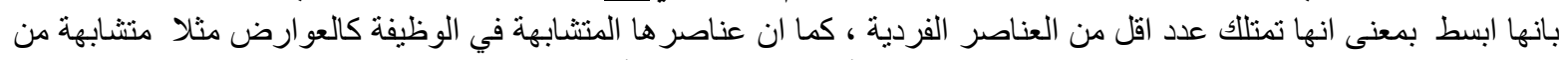

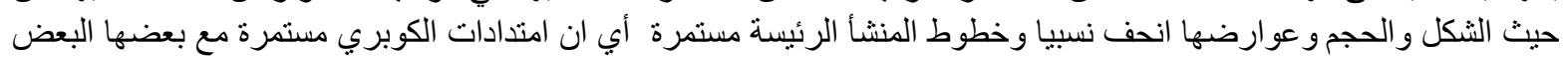
اوتبدو للعيان بأنها مستمرة

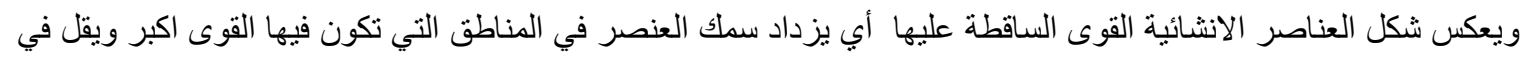

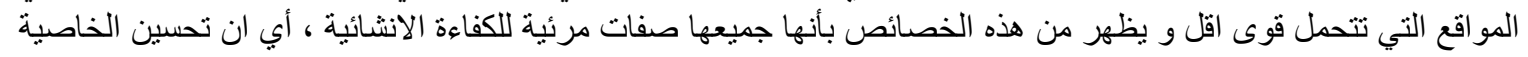

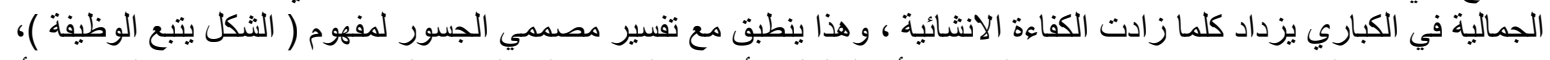

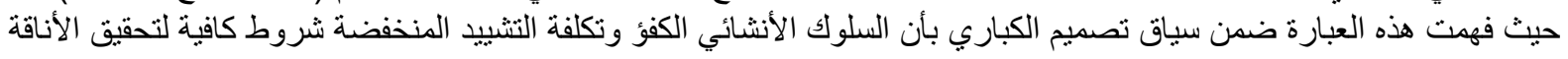




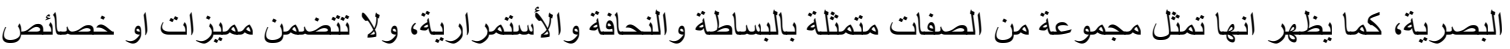

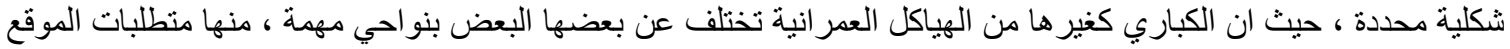

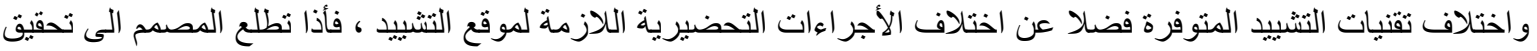

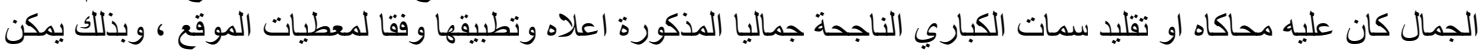
تلخيص الجو انب الأساسية المعتمدة لخلق كباري ذات صلفة جمالية وفق المفهوم الانشائي

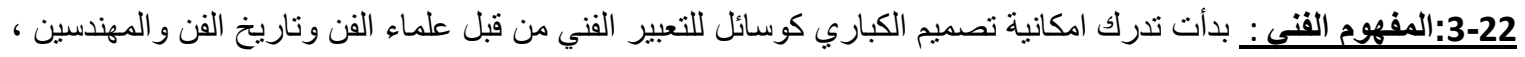

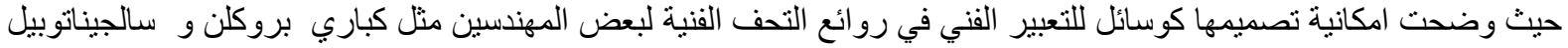

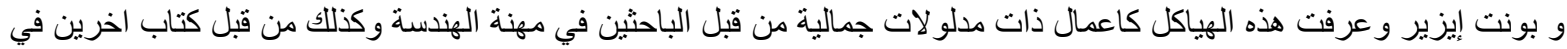

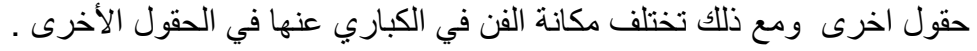
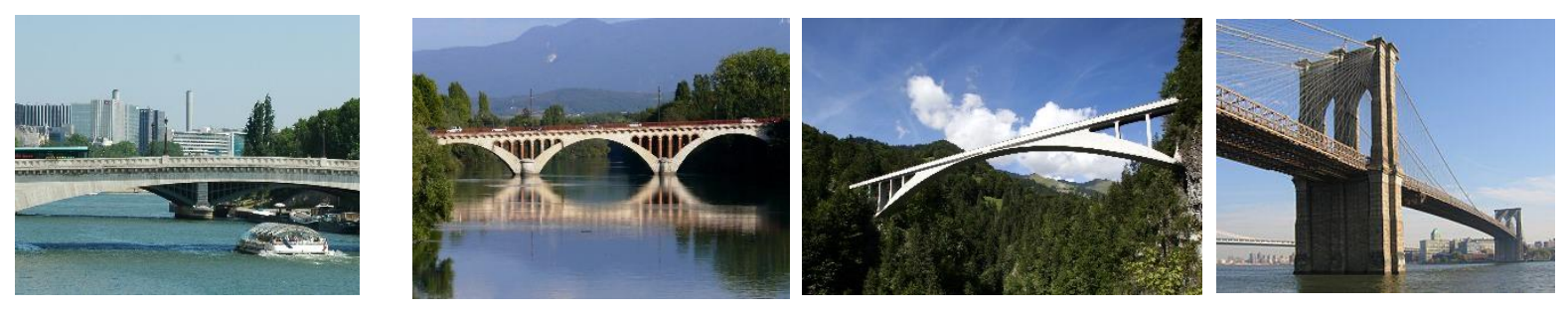

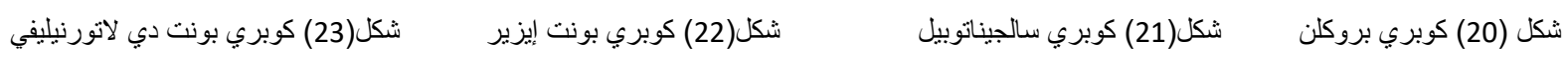

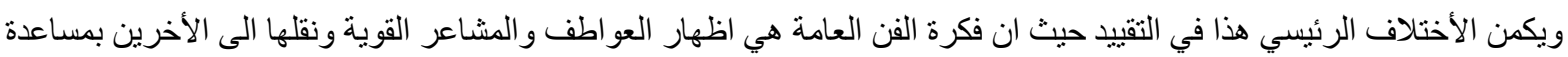

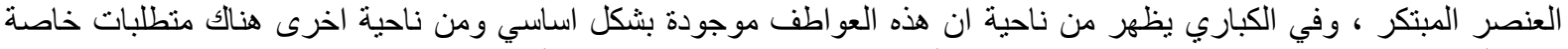

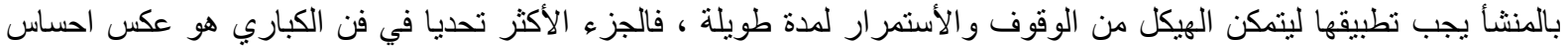

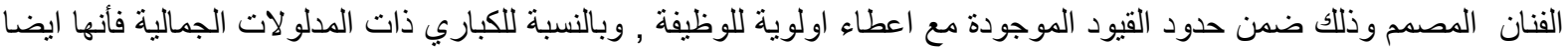

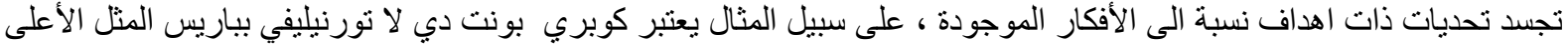

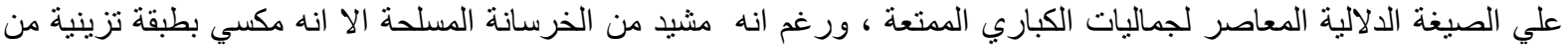

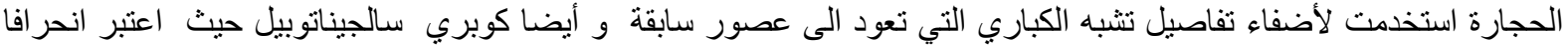
راديكاليا عن الذوق الفني الثائع حيث انه استخدم المنشأ الخرساني نفسه ليكون وسيلته في التعبير

23:المبادئ الأسساسية الجمالية لهياكل الكباري:إذا كان هيكل الكوبري يتمتع بمظهر جميل من الناحية الجمالية فسوف

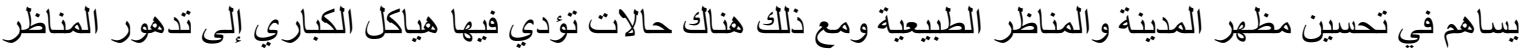
الطبيعية بسبب مظهر ها القبيح و هذا هو السبب في أنه يجب الإهنمام بالمبادئ الأساسية لتحقيق الناحية الجمالية لهياكل النياكل

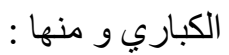

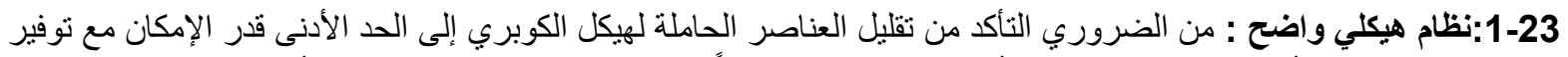

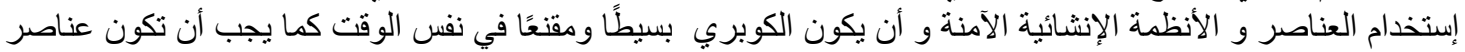

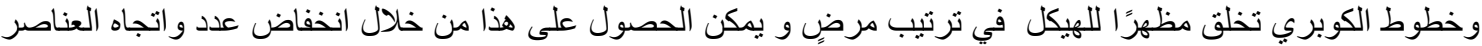

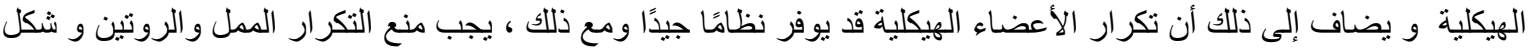

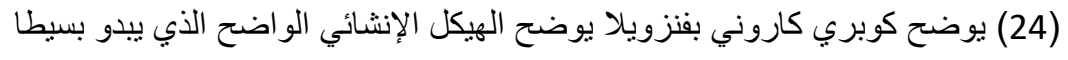

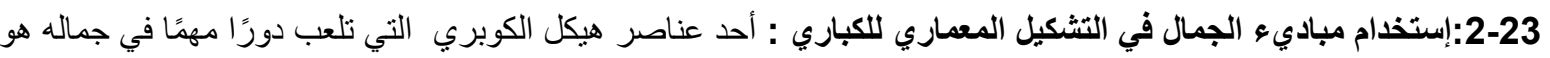

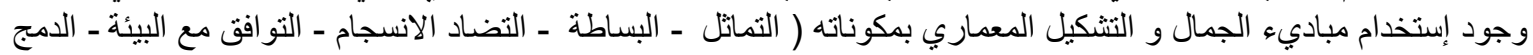

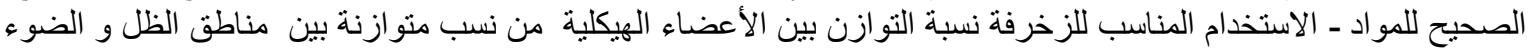

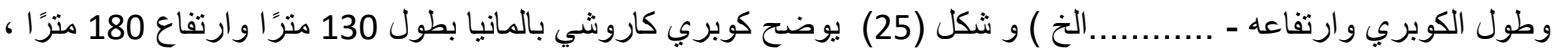
مما جعل الجسر يتلاعم مع الو ادي بشكل صحيح وله شكل مكافئ في الاتجاه العرضي مما يجعل الجسر ممنعًا من الناحية الجمالية

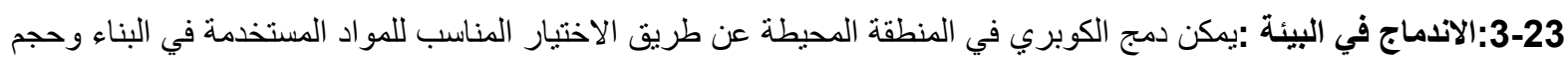

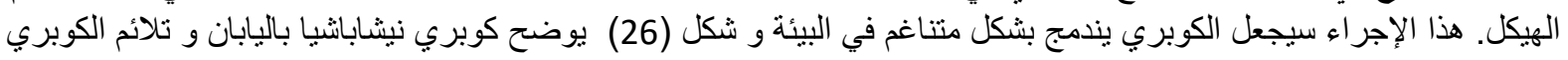
مع الطبيعة هذا

4-23:اختيار المواد : ينم اختيار المو اد المناسبة من حيث القدرة على التحمل والمظهر. على سبيل المثال ، يجب استخدام الخرسانة في بناء الدعامات بينما يستخدم الفو لاذ في بناء الروابط كما يمكن استخدام القو الب لتوفير نسيج لمساحة كبيرة من الخرسانة ولكن 
يو وصى بالمساحات الصغيرة لتركها ناعمة من المكن تطبيق الأحجار الطبيعية على تبطين مساحات كبيرة من الدعامات و والأرصفة.

5-23:الالوان :يلعب اللون دورًا مهمًا في توفير مظاهر مبهجة بصريًا لهيكل الكوبري و هناك حالات يحتاج فيها هيكل الكوبة الكوبري

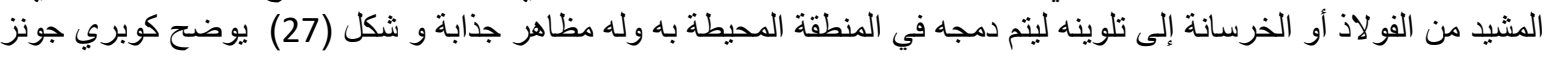

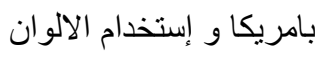

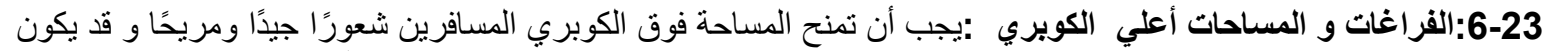

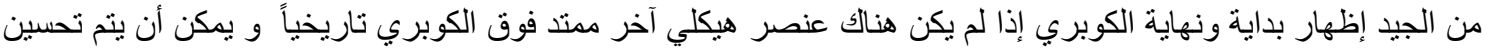

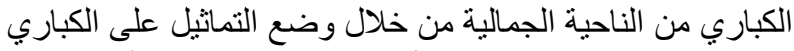

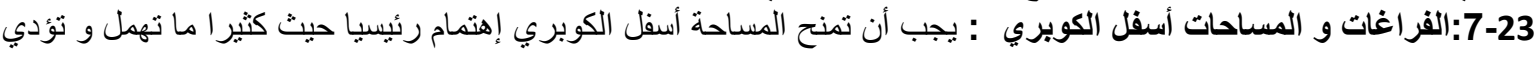

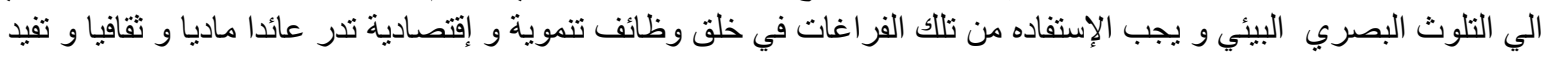

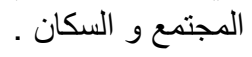

8-23البساطة :البساطة هي العامل الأكثر أهمبة عندما يتعلق الأمر بهيكل الكوبري دون استخدام عناصر للتحسين الجمالي. يجب أن يوفر الثكل الهيكلي رؤية مبهجة من النياطية الناحية الجمالي النيا

9-23-23إنارة الكوبري:يمكن أن يحسن المظهر الجمالي لهيكل الكوبري في الليل. حسنت التكنولوجيا الحديثة إضاءة الكوبري وتوفر

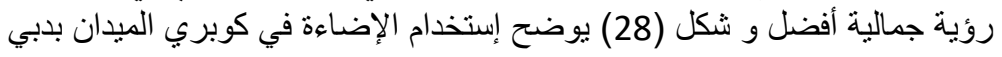

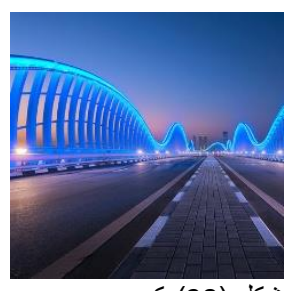

شكل (28) كوبري

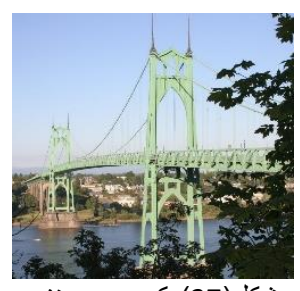

شكل(27) كوبري جونز

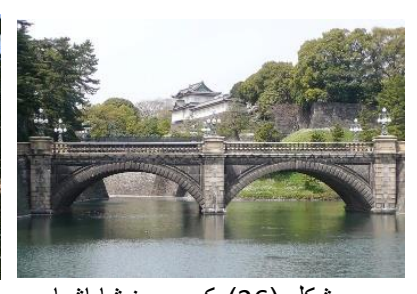

شكل (26) كوبري نبشاباثيا

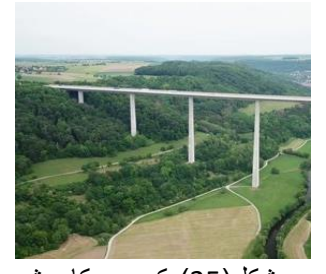

شكل(25) كوبري كاروشي

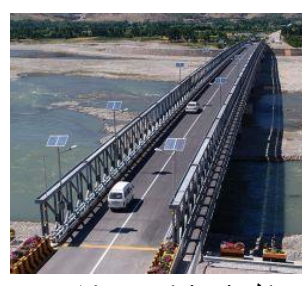

شكل (24) كوبري كاروني

24:عناصر التصميم المرئى الحيوية التى يجب أخذها في الاعتبار أثناء عملية التصمير: يجب مر اعاة كل من :

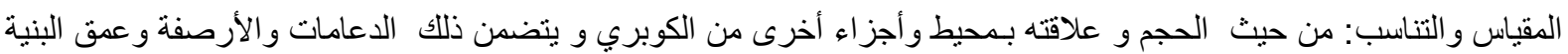

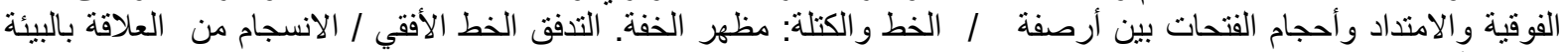

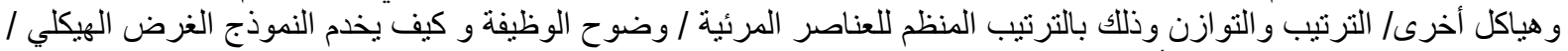

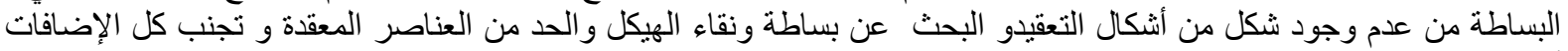

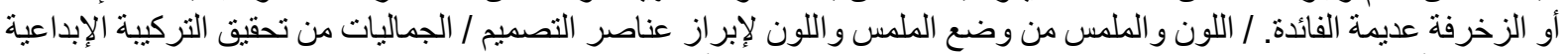

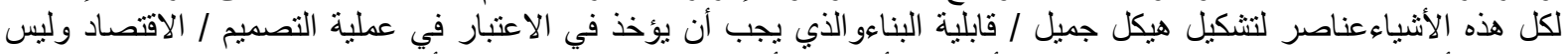

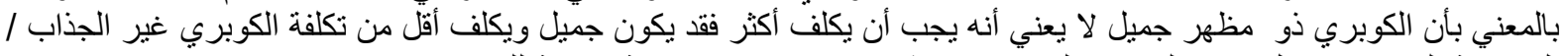
المشاركة المبكرة من قبل فريق التصميم المتمرس مع ذكاء توفي اندر نتائج اقتصادية مناسبة للكوبري

25: النتائج المترتبة عن مشاركة المعماري في تصميم الكباري: يجب توقع عدة نتائج ناتجه عن التصميم الجيد

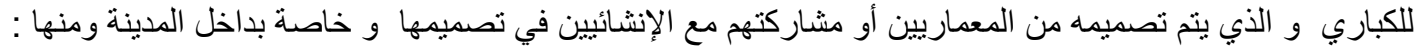

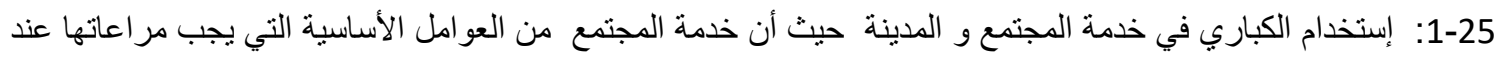

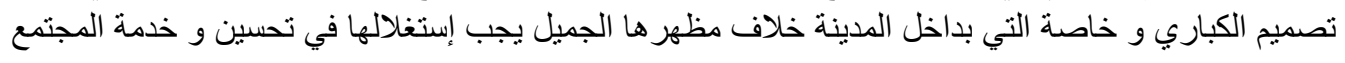
2-25: توفير زو ايا متنو عة لرؤية الكوبري كمعلم جديد للمدينة و يكون علامة مميزة للمنطقة و المدينة تستمر عقود 3-25: ان تكون الكباري ذات شكل جمالي مناسب للمنطقة و ليس كتل خرسانبة آمنه فقط تشوه منظر البيئة المنفذ بها 4-25: تناغم الكباري مع البيئة المنفذ بها و الوصول الي كباري مستدامة 5-25 : تصميم الكوبري يجب أن يكون فريدا لتحديد المستقبل المعماري للمناطق الحضرية 6-25: تصميم الكباري يجب أن يكون لآئقا و يحترم التراث المحلي احتراما كاملا 
دور المهندس المعماري في تصميم الكباري كعنصر جمالي و تنموي بلاخل المدينة

7-25 : يجب أن توفر الكباري مؤشرات على الهوية الحضرية للمدينة و منها البلاد

8-25: معالجة المشاكل المرورية و إنسياب الحركة بالطرق

9-25: إثنتر الك المهندسين المتخصصين و الفنانين في التصميم يعطي نموذج

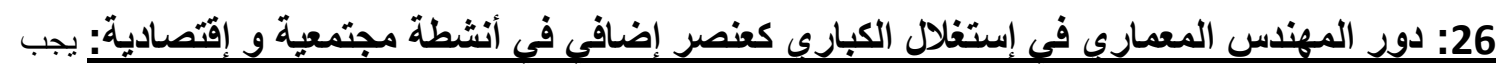

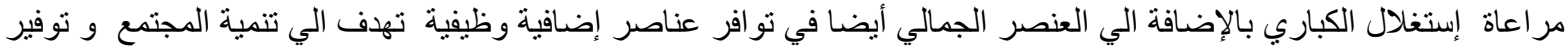

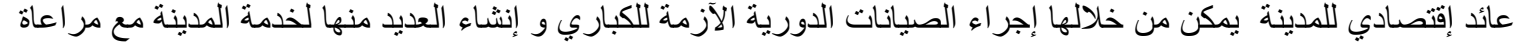

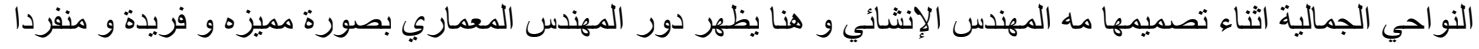

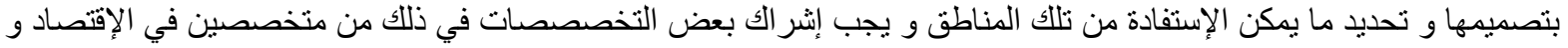

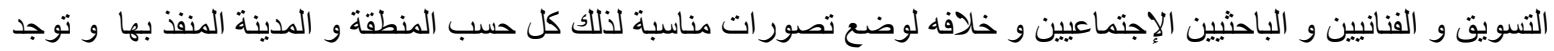

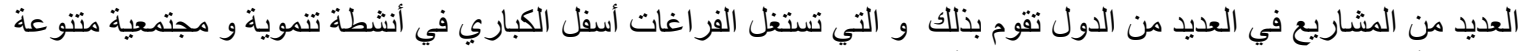
ومنها الأمثلة التالية و التي توضح العند الإستغلال الأمثل للكباري كعنصر مؤثر بالمدينة

1-26: إنشاء شريان حيوي للمشاة وراكبي الدراجات تحت طريق غاردينر السريع بالمدينة تورنتو - كندا : يشمل عده عناصر خدمية من ممشي ومناطق جلوس و لعب أطفال و مدرج مفتوح و مضمار لركوب الدرجات بالإضافة الي

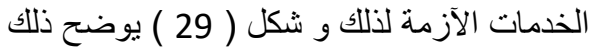
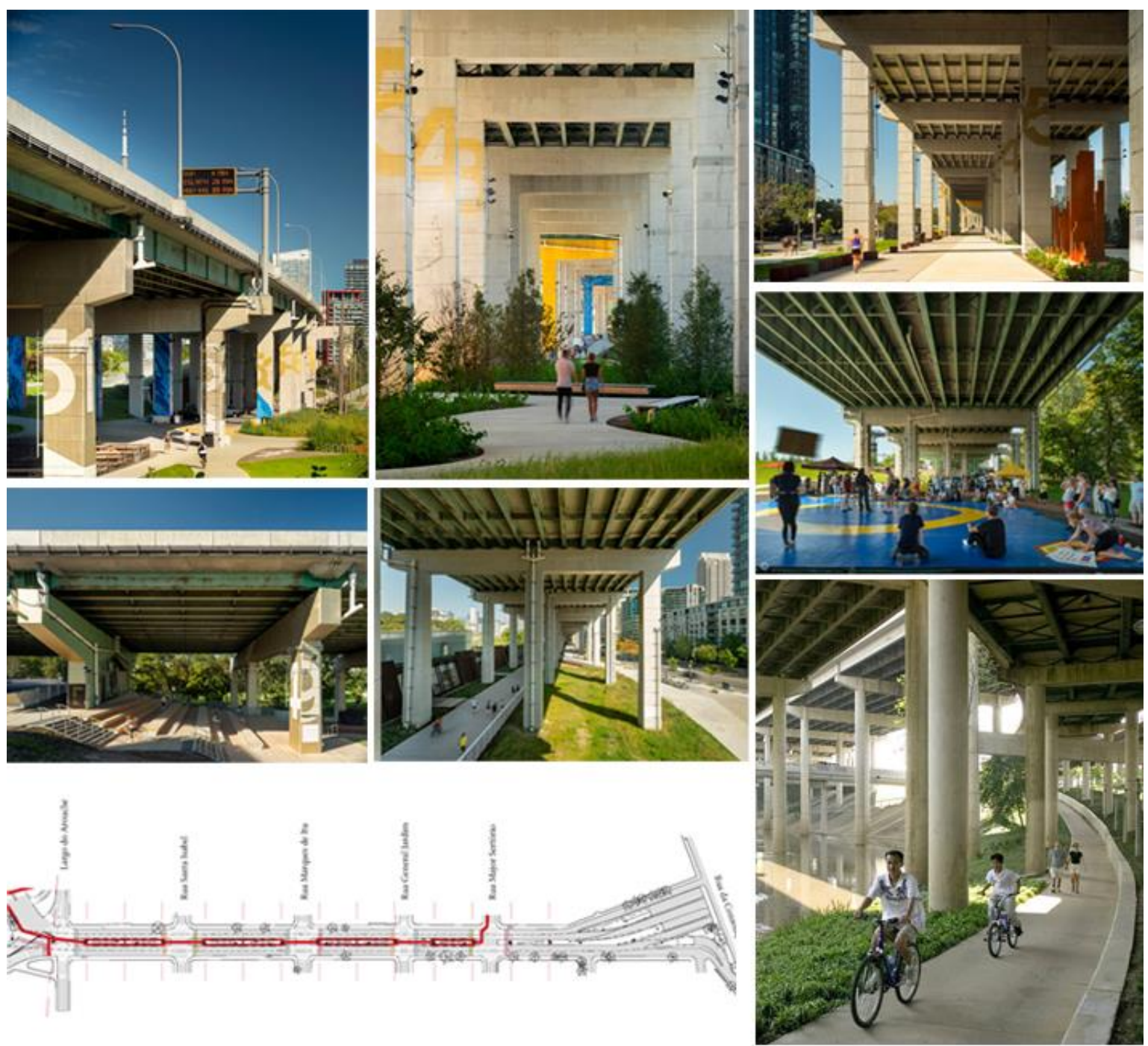

شكل (29) تنفيذ حديقة بنت واي تحت كوبري غاردينر في تورونتو - كندا 


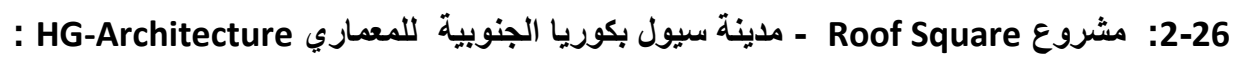

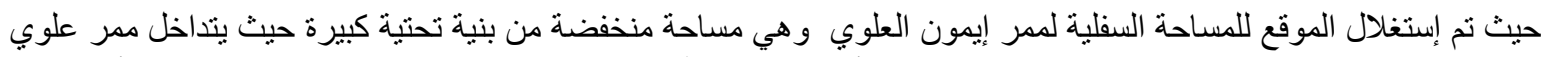

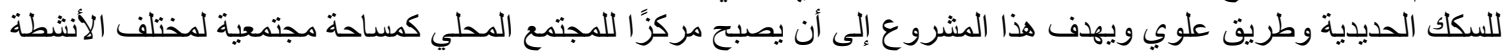

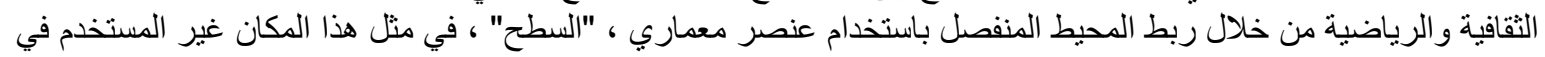
المدينة و هو مشروع لتحسين البيئة المعيشية و المشهد الحضري للمنطقة لمناطق مظلله و توفر بيئة مفعمة بالحيوية و شكل ( يوضح ذلك
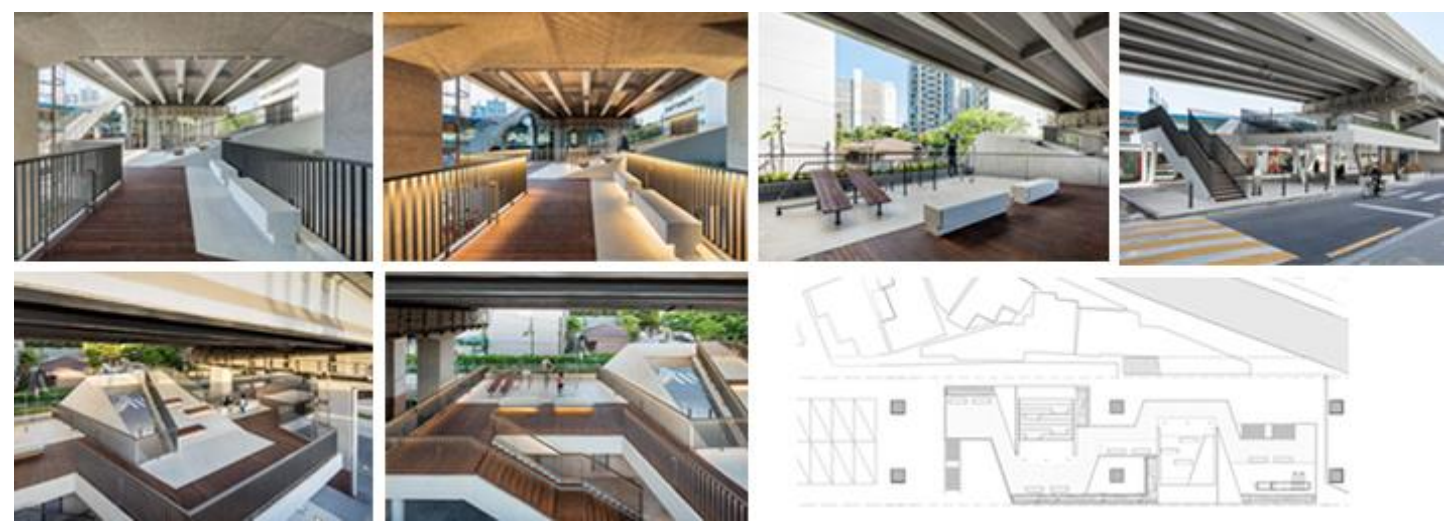

HG-Architecture بكوريا الجنوبية للمعماري Roof Square مشرو (30) مشروع

3-26: مشروع منتزه للتزحلق و الجلوس بمنطقة رامبشوفسباركين بأستوكهولم ( أسفل الكباري ) : تم إعادة تصميم المساحة السلبية أسفل الطرق السريعة و الكباري كمنتزه للتزلج ومساحة عامة مع تو افر الأنشطة التي تخدم عليها
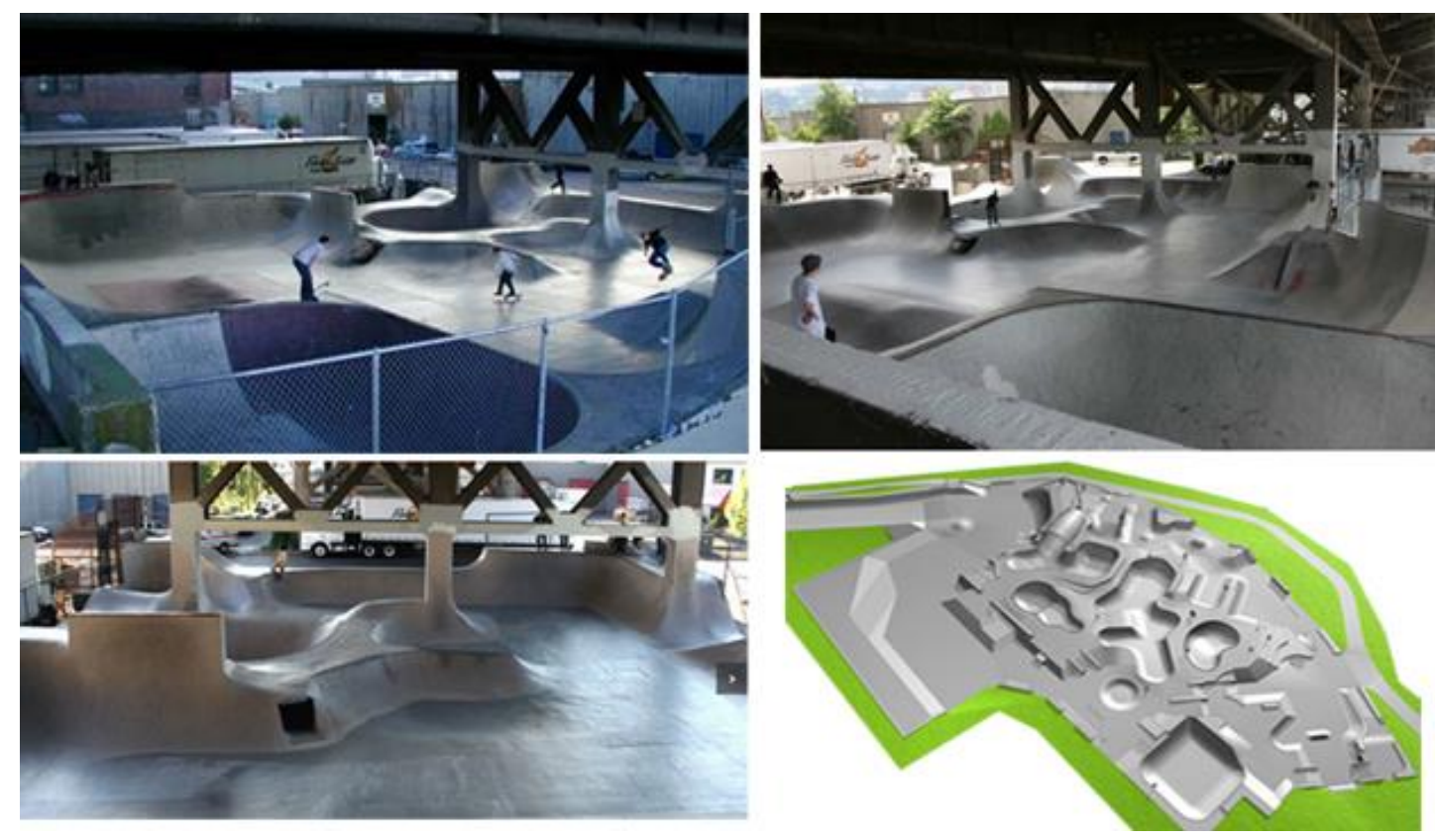

شكل (31) مشروع منتزه للتزحلق و الجلوس بمنطقة رامبشوفسباركين بأستوكهولم

4-26: مشروع "زهور العنقاء" بمتنزه فينيكس القديم -طريق جارسكوب ، غلاسكو ، اسكتلندا :

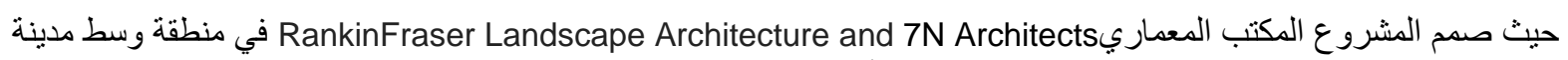

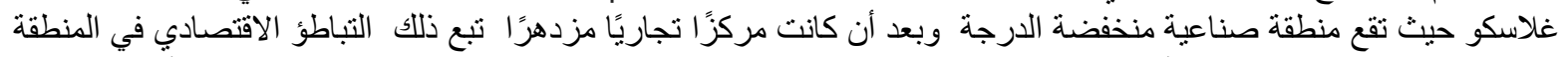

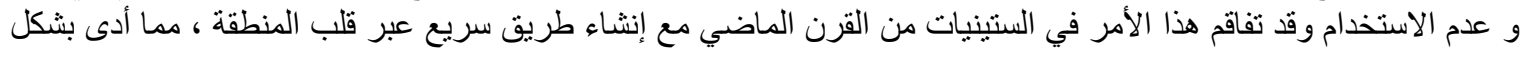


فعال إلى قطع رابط مهم بين طرق المدينة ووسطها , ومن أجل تجديد هذا التصور السلبي تم تتمية المنطقة بتوفير عناصر تسمح

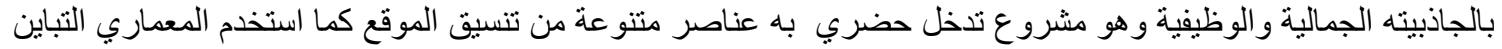

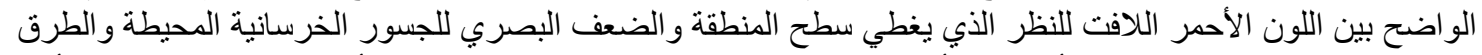

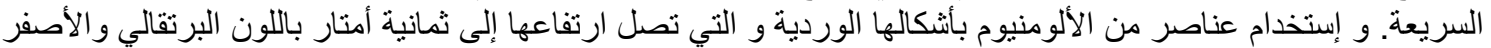

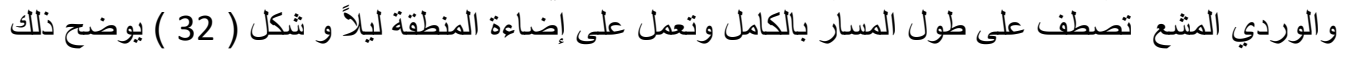
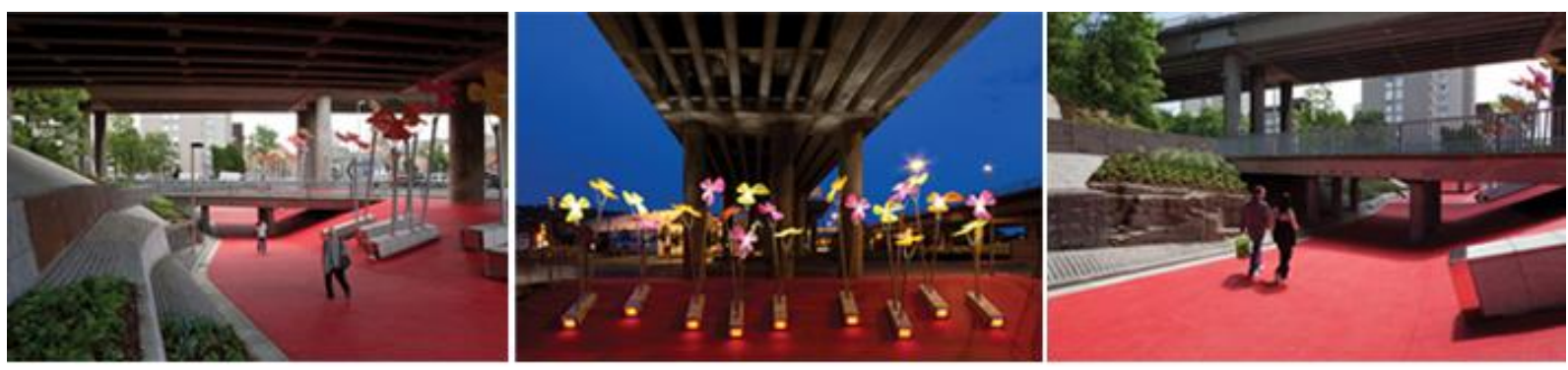

شكل (32) مشروع "زهور العنقاء" بمتنزه فينيكس القديم -طريق جارسكوب ، غلاسكو ، اسكتلندا

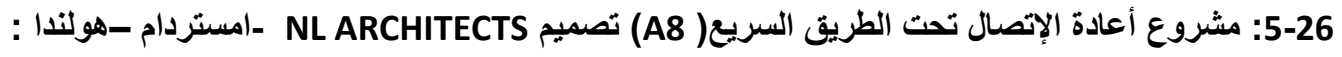

يقع المشروع في منطقة كوج أند زيدان بالقرب من أمستردام تقع على نهر الزان حيث تم إنشاء طريق سريع جديد في أو ائل إنل

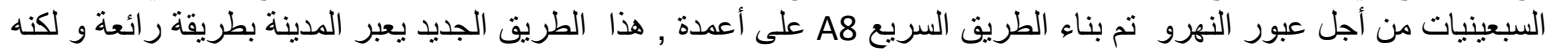

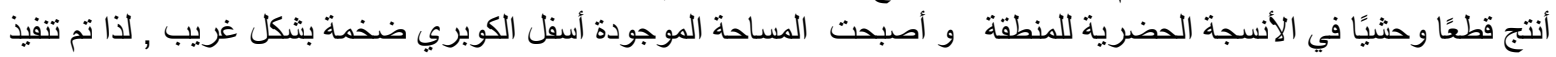

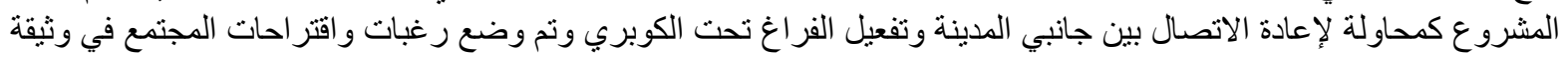

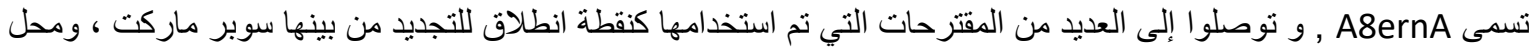

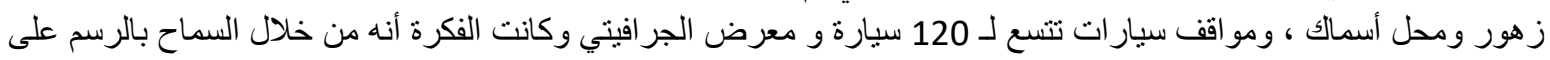

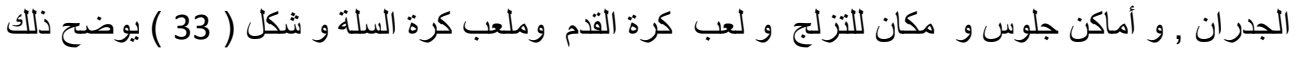
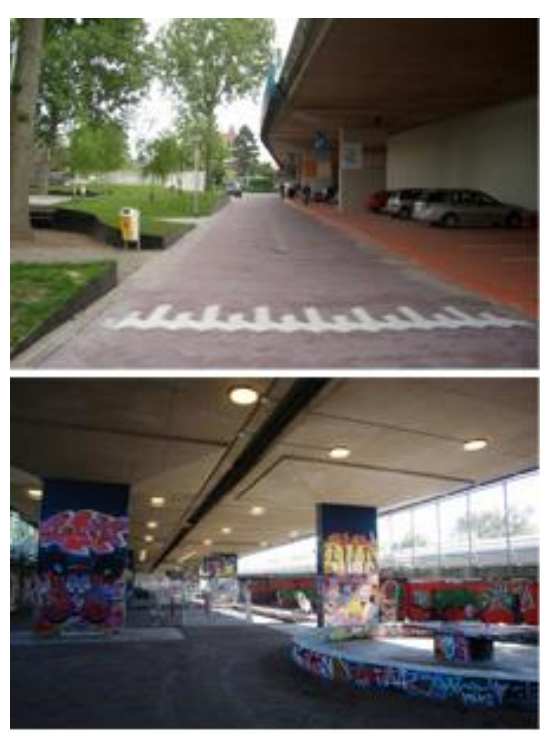

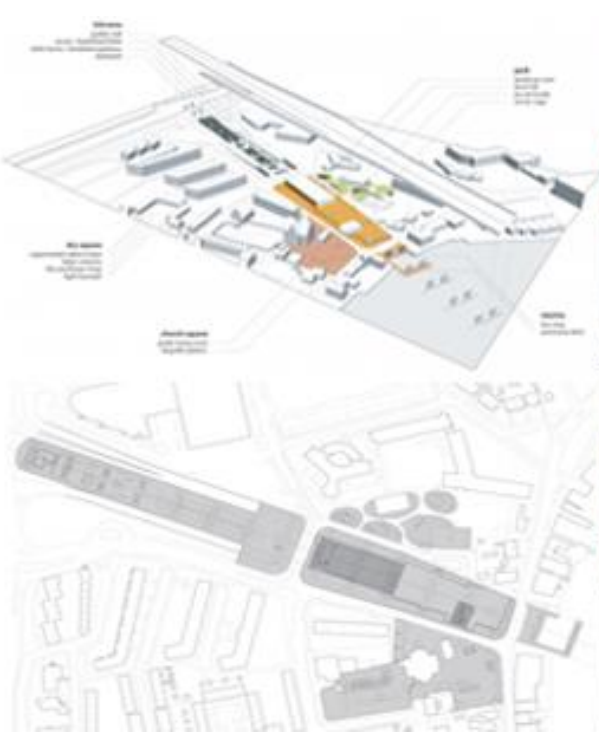

شكل (33) مشروع كوج آن دي زان - امستردام -هولندا

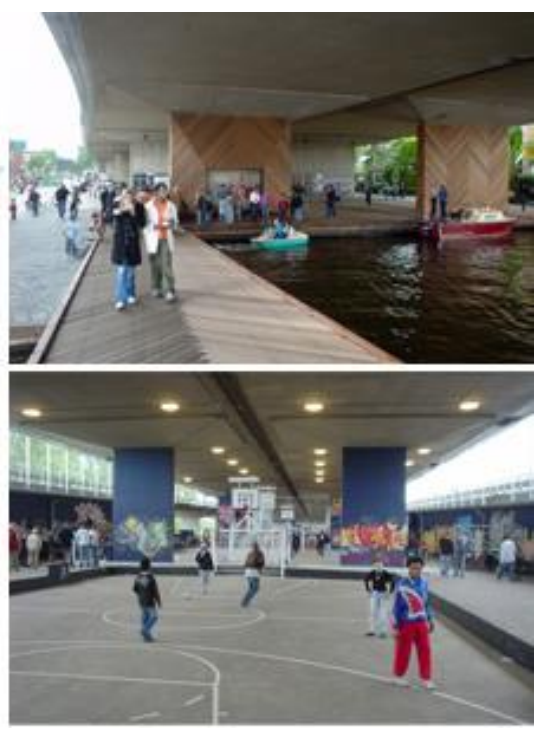


5-26: نماذج متنوعة لإستفلال أسفل الكباري في أنثطة تنموية وإجتماعية و ثقافية ........الخ :
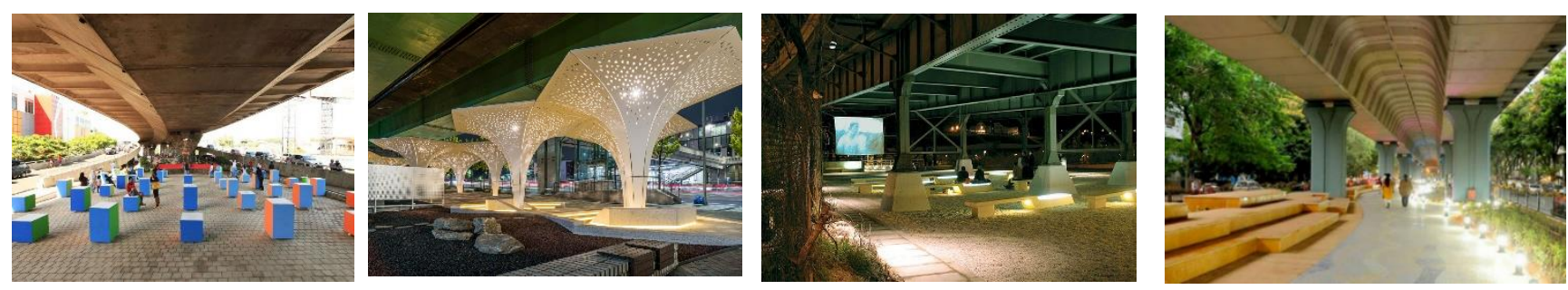

أنكال (34-33-35-36) توضح إستغلال أسفل الكباري في مناطق جلوس متنو عة
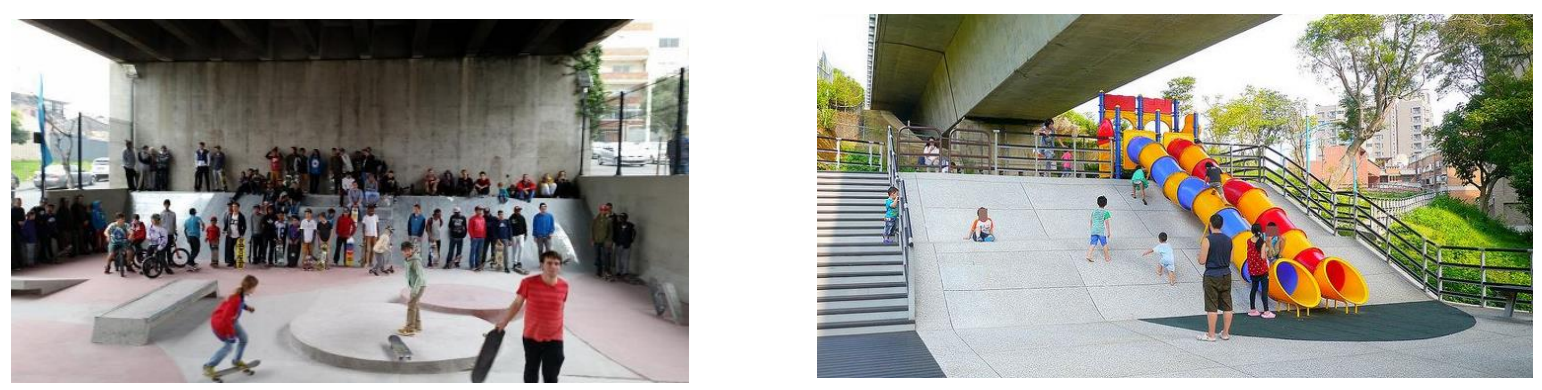

أشكال (38-37) يوضح إستغلال أسفل الكباري في مناطق لعب أطفال متتو عة
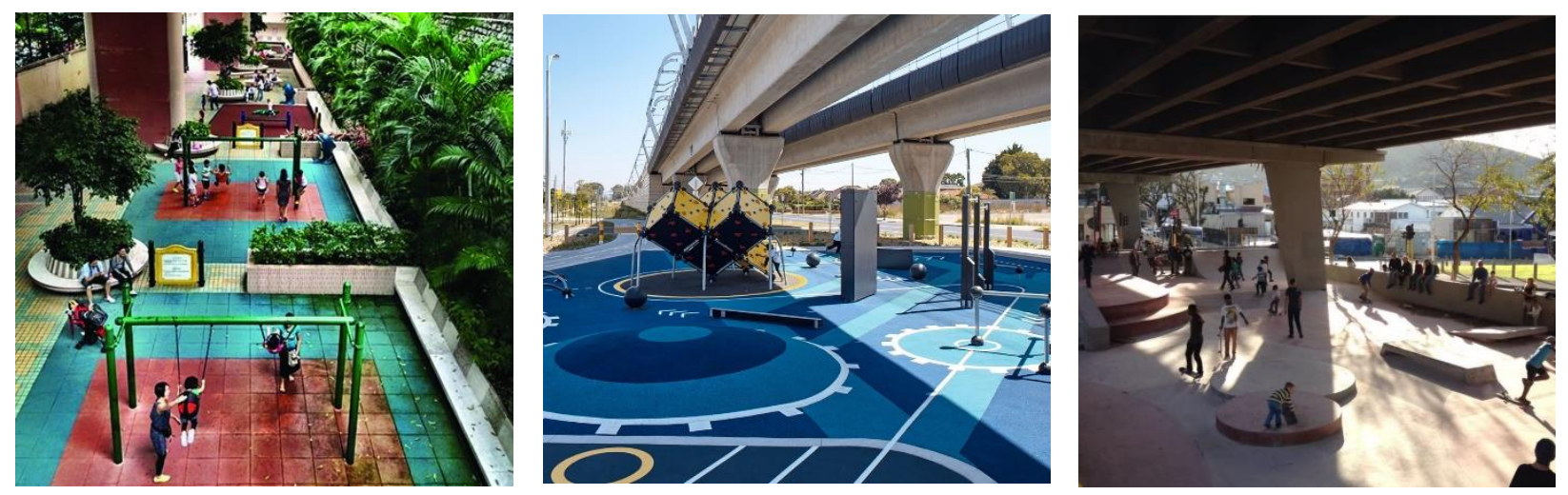

أشكال (40-41-40) يوضح إستغلال أسفل الكباري في مناطق لعب أطفال متنو عة
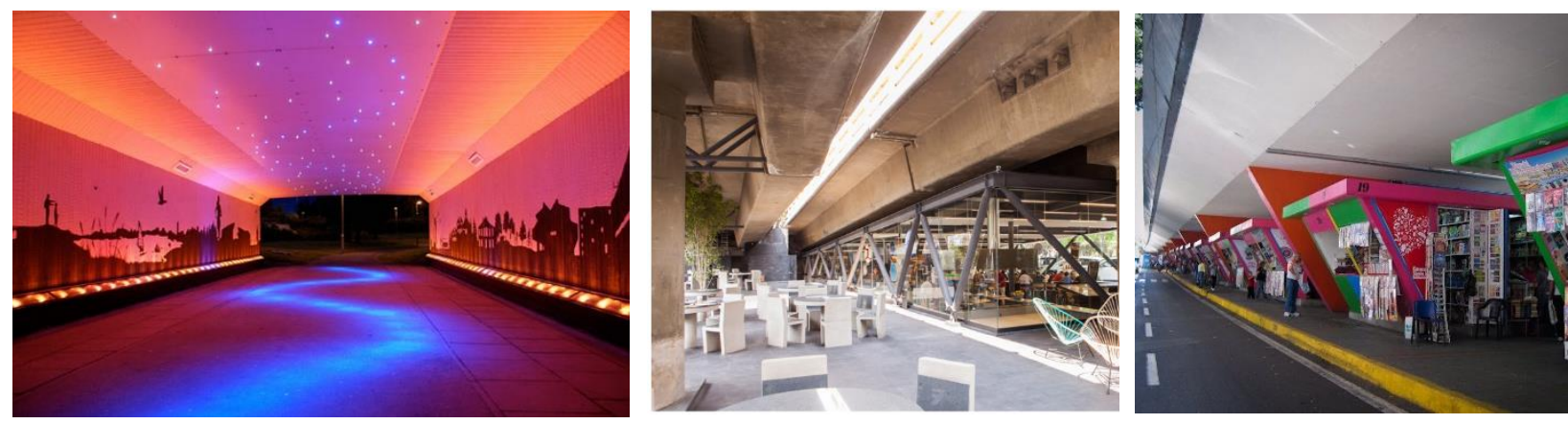

أشكال (42-42-43) توضح إستغلال أسفل الكباري في ( مكتبات - مطاعم- قاعةعرض ) 

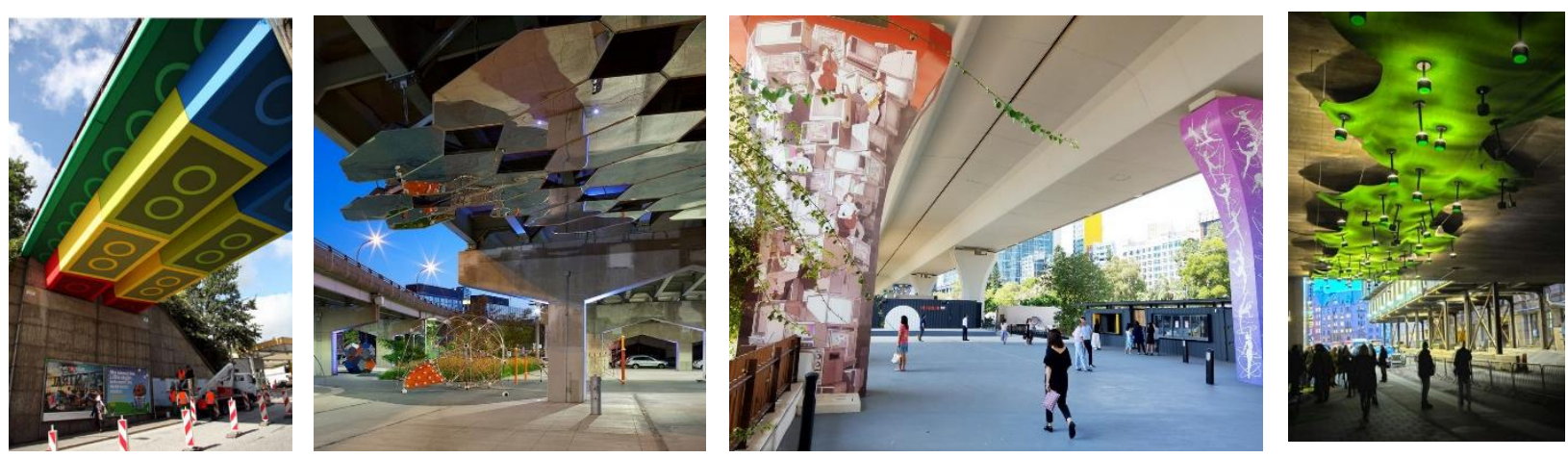

أنشكال (45-45-48-48) توضح إستغلال أسفل الكباري في أعمال فنبة و تلوينها بالمظهر المبهر

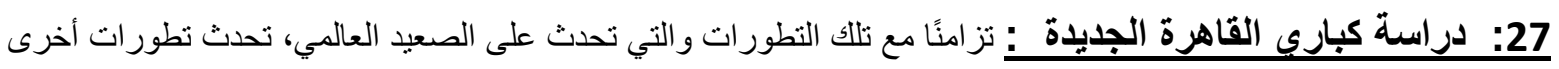

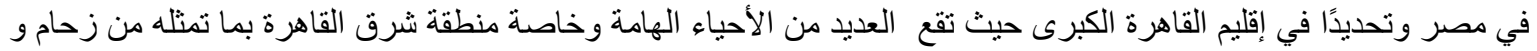

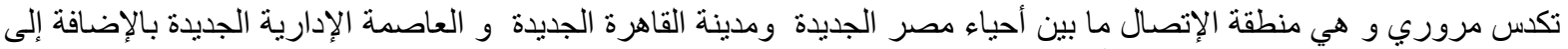

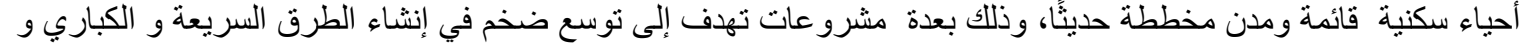

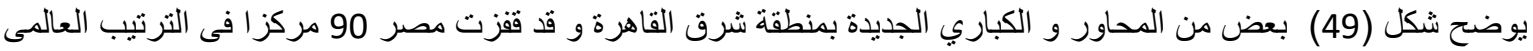

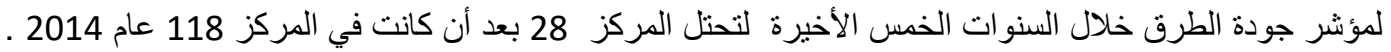

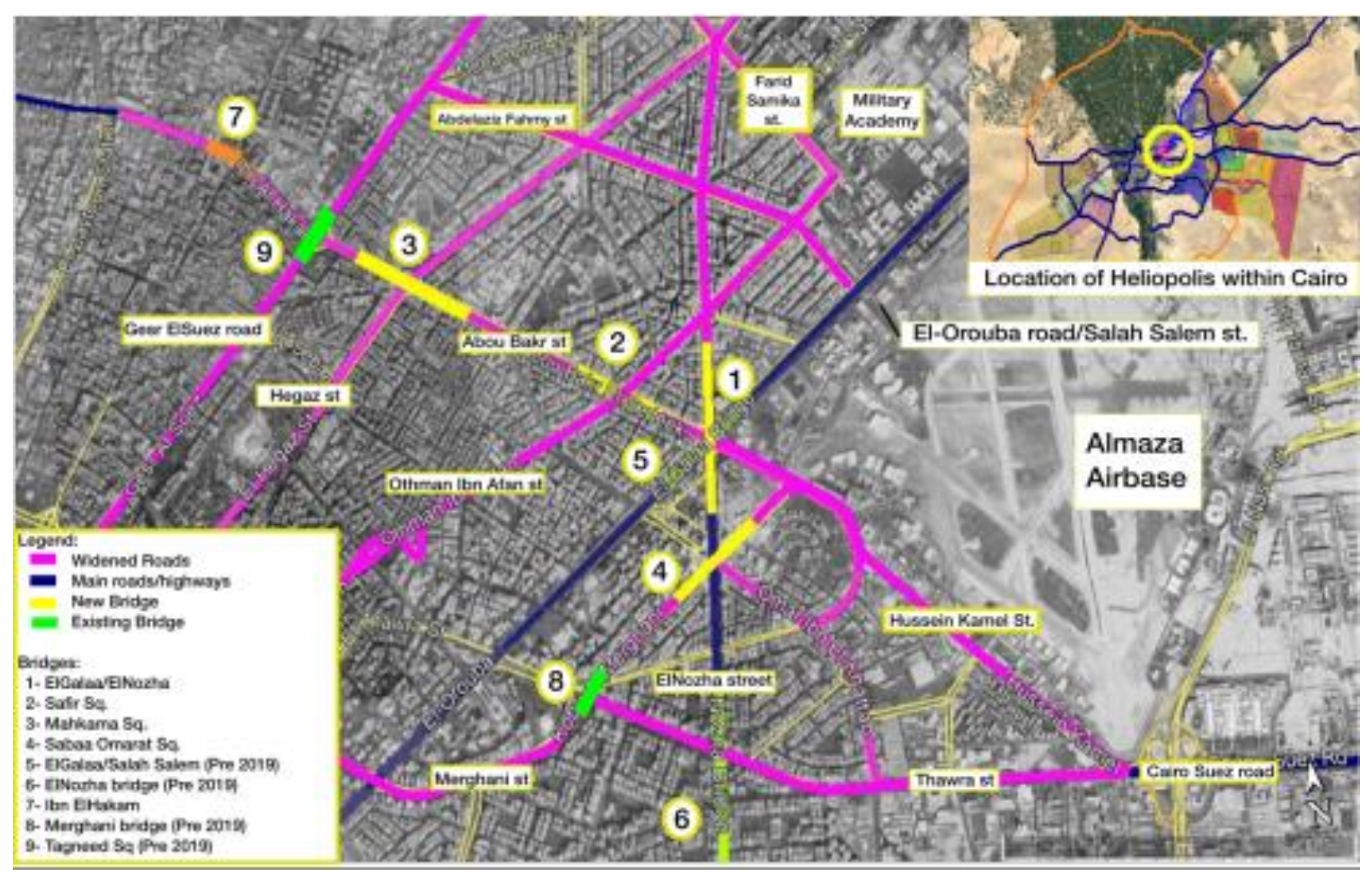

شكل (49) يوضح بعض من المحاور و الكباري الجديدة بمنطقة شرق القاهرة

ويعد هذا المخطط من أهم المشروعات التي تتبناها الدولة حاليا، ويشمل تطوير الطرق و النقل و الكباري و تمت عمليه التطوير

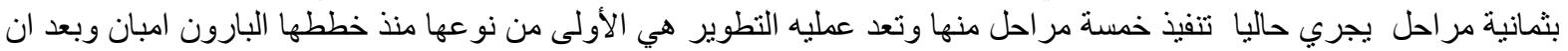

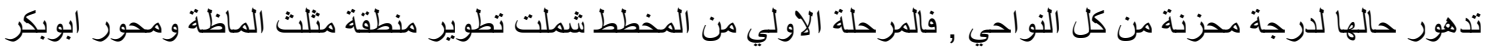

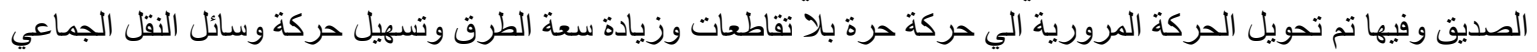

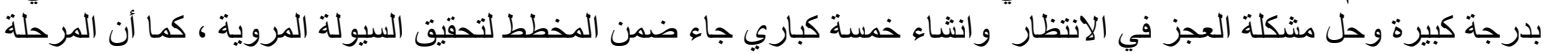

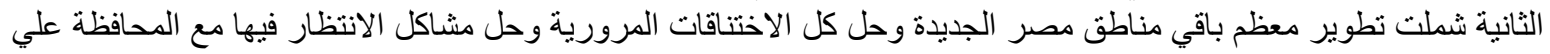

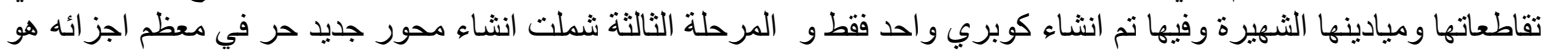




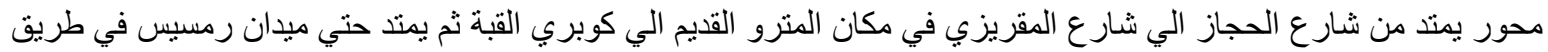

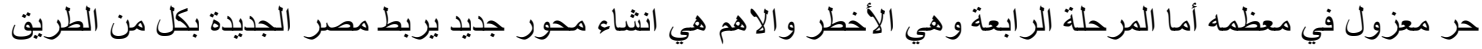

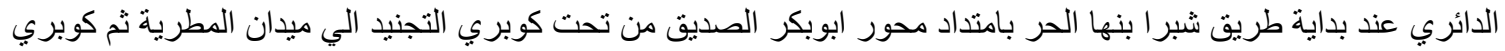

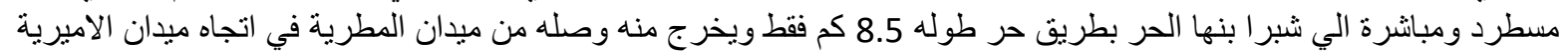

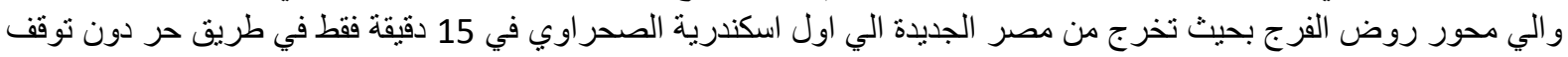

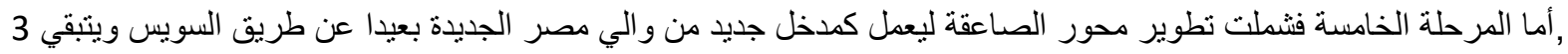

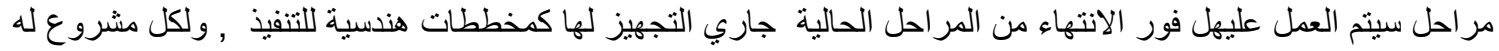
الإيجابيات و له السلبيات و أن الشرور الإناه الناجح هو التي تغلب عليه الإيجابيات بصورة رئيسية و مؤثره لذا سيتم تحديد الإيجابيات و السلبيات لمشاريع الطرق و الكباري بالقاهرة الكبري

\section{1-27: إيجابيات مشاريع الطرق و الكباري بالقاهرة الكبري : تتمثل إيجايبات تلك المشاريع في التالي :}

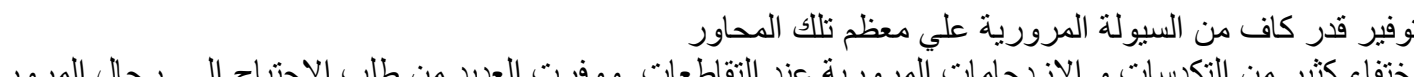

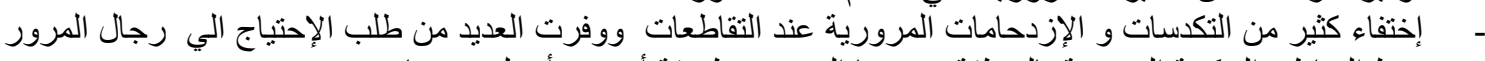

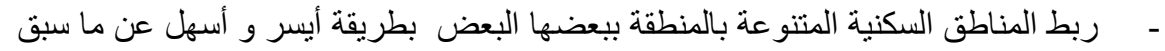
ربط المناطق السكنية بالدحاور الرئيسية للمدينة و الددن و الجمعات المحيطة بهاو العاصية العية الإدارية بطريقة ايسر و - - - إستغلال بعض المناطق أسفل بعض الكباري في نوفر أنثطة إقتصادية متمثلة في أماكن للمطاعم و الكافتريات

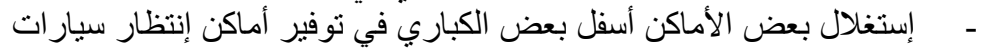

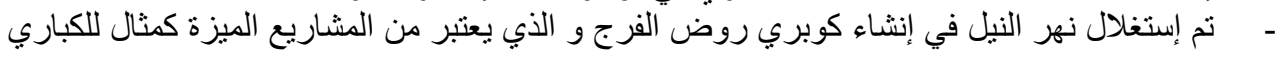

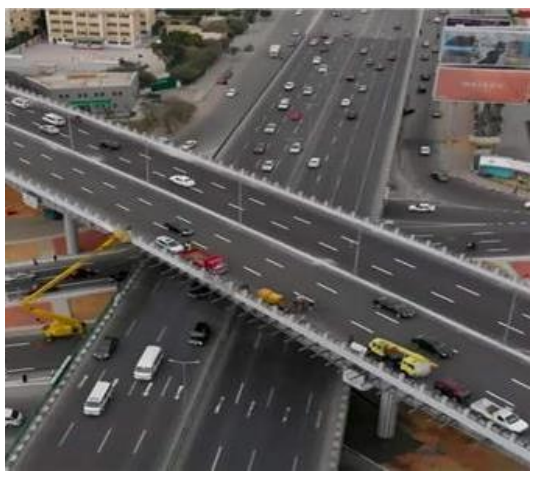

شكل (52) يوضح السيولة المرورية في المدينة

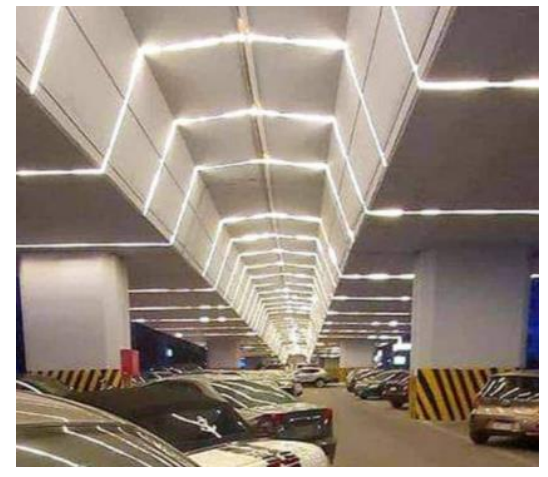

شكل(51) يوضح إستغلال أسفل الكباري

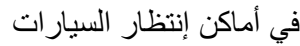

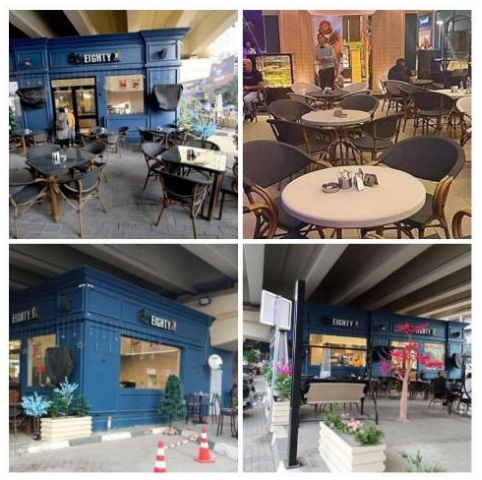

شكل (50) يوضح إستغلال أسفل الكباري في أنشطه مطاعم و كافتريات

\section{1-27: سلبيات مشاريع الطرق و الكباري بالقاهرة الكبري : تتمثل سلبيات تلك المشاريع في التالي :}

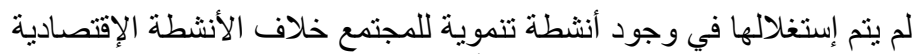

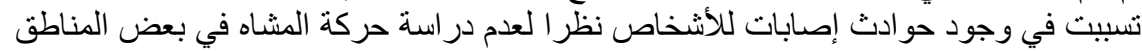

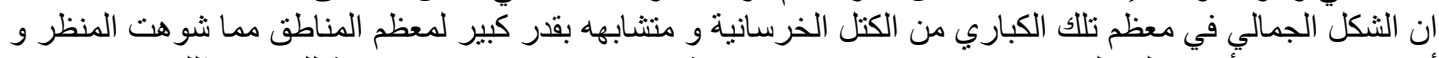

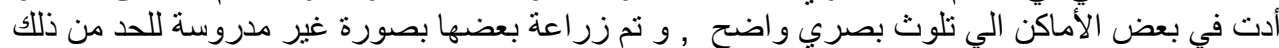

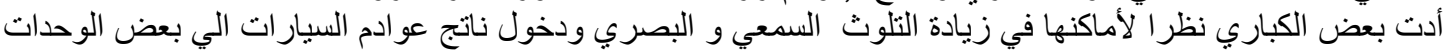

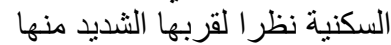
وجود بعض الكباري ملاصقة للعمار ات السكنية أد الي الإزعاج المستمر للسكان ما سيؤدي الي أمر اض نفسية و عصبية لاحقة لهم

وجود بعض الكباري في بعض الأماكن ادي في تدهور بعض الأماكن أسفلها و وجود مناطق عشوائية أسفلها

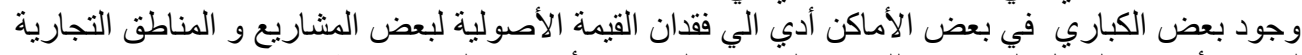

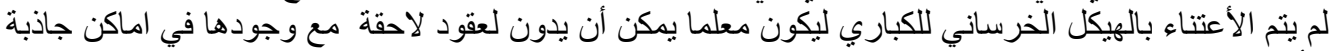

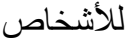

لم يتم الدار اسة المرورية التامة لبعض التقاطعات و الكباري أدت الي تكدس مروري ليس بالأفضل عما كان و من تللك

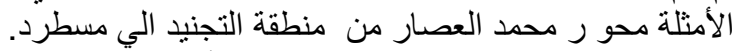
تدهور القيمة الحضارية و التراثية لبعض الأماكن مثل بعض مناطن منطف مصر الجديدة و التي كان لها طابع معماري خاص 
دور المهنس المعماري في تصميم الكباري كعنصر جمالي و تنموي بلاخل المدينة
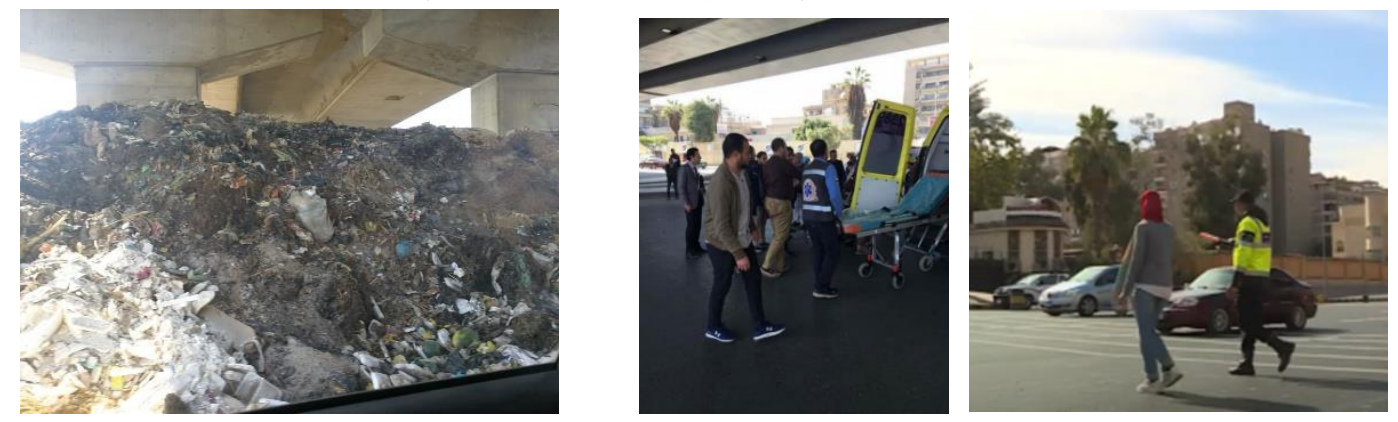

أشكال (53-54 ) يوضح عدم توفر كباري مشاه مما أثرت علي زيادة معدلات شكل ( 55) يوضح وجود قمامات و عدم استغلال اسف الكوبري

الحوادث و خاصة عند منازل الكباري
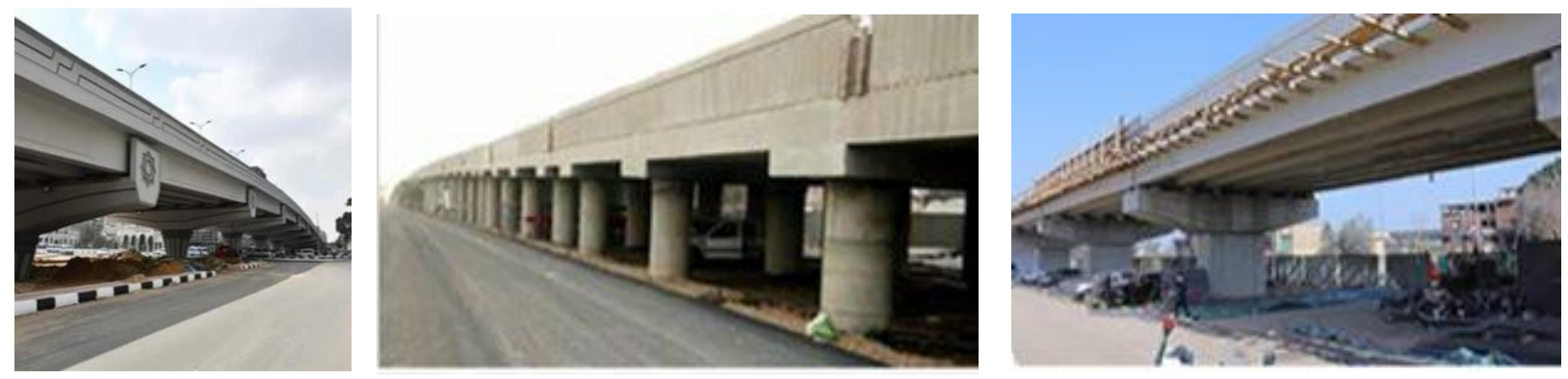

أشكال (56-58-58) توضح الكتل الخرسانية للكباري دون لمسات جمالية في تشكيل الكباري لتكون معلما بالمنطقة
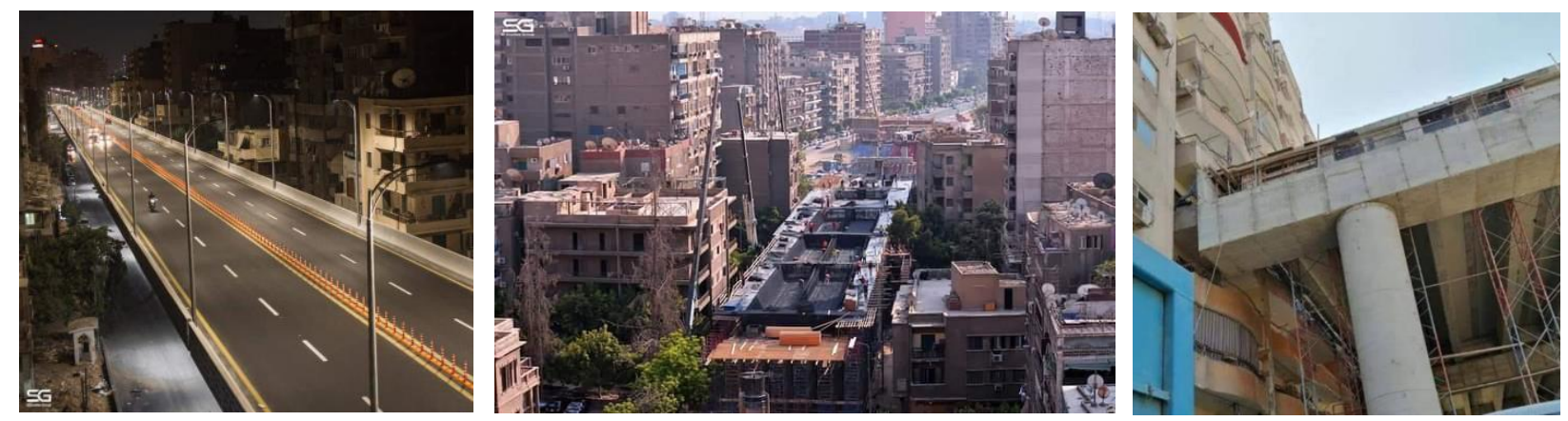

أثكال (60-61-60) توضح تلاصق الكباري مع العمارات بصورة غبر مدروسة ادت لتلوث بصري و سمعي و بيئي
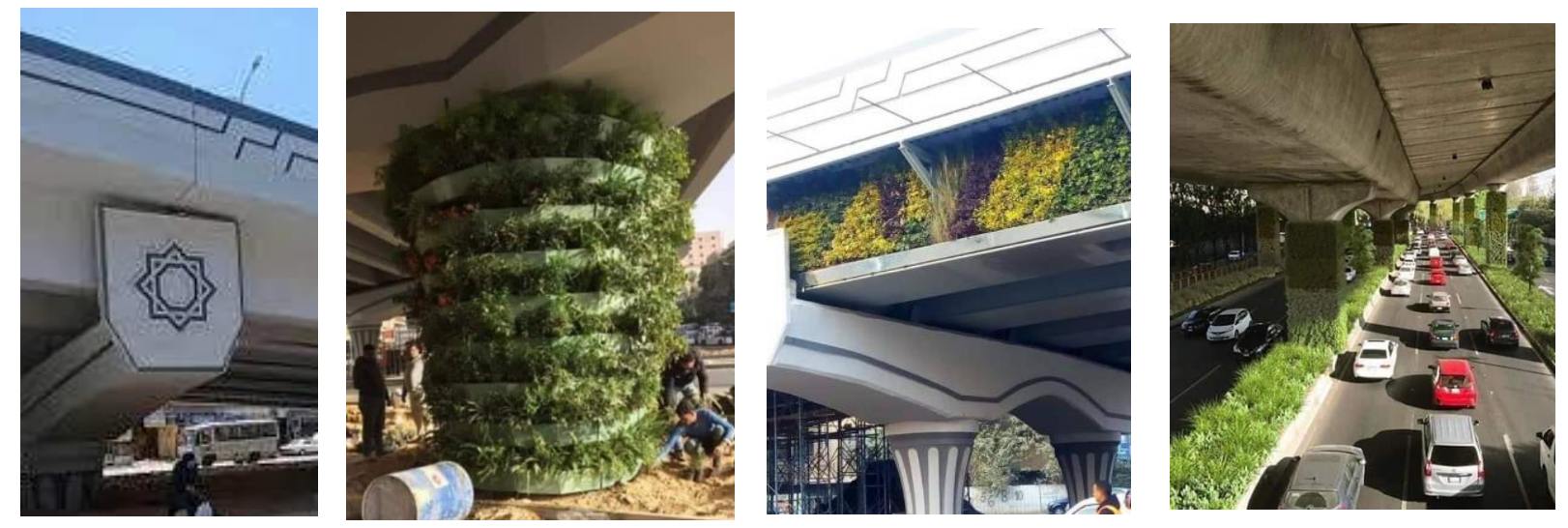

أثكال (62-63-63-63 ) نوضح محاولة إطفاء لمسة حضارية و بيئية بزر اعة الكباري و أعمدتها وتزبين الخرسانات كمقترح للحد من الكتل الخرسانية بداخل المدينة 
28: النتائج و التوصيات : من الدراسة تم التوصل الي عدة نتائج و توصبات محددة و تتمثل في التالي :

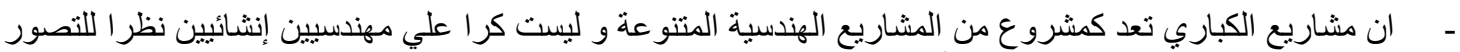

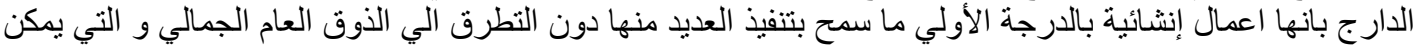

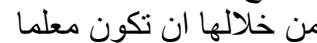

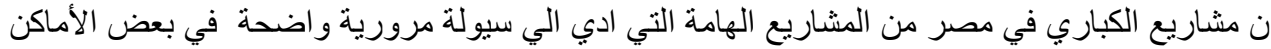

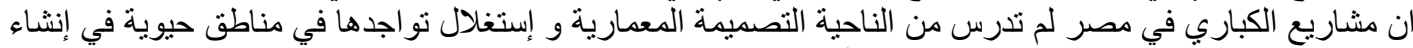

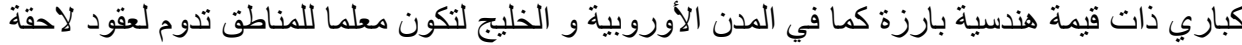

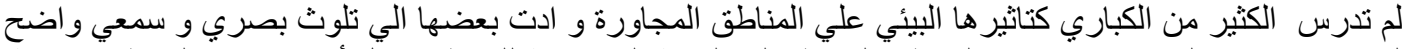

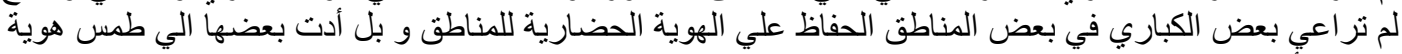

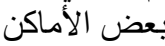
لم تستغل المناطق اسفل الكباري الا في انثطة اقتصادية بالدرجة الأولي و لم تستغل بعضها في انشطه تتموية و إجتماعية و ثنقافية أدت بعض الكباري الي وجود مناطق عشو ائية و مهملة في بعض الكباري و التي نفذت في مناطق عشو ائية مما ادت الي

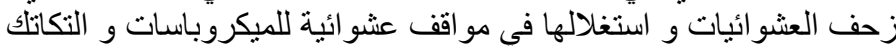

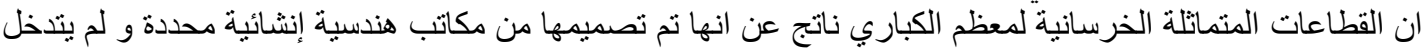

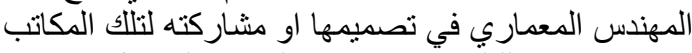

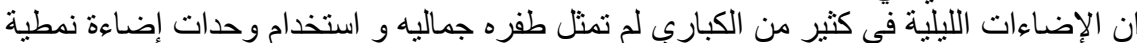
ان الأنشطة المنفذة اسفل الكباري الآن انشطة إقتصادية فقط و لم توفي باماكن انتظار مناسبة لها لهاء

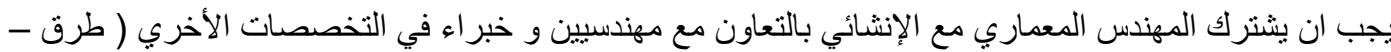

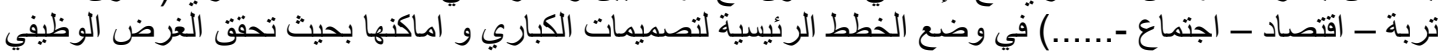

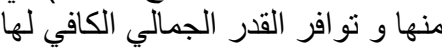
استغلال اسفل الكباري في انشطة تنموية اخري للمجتمع كما في المشاريع المشار اليها في البحث و لا تقتصر علي

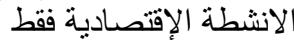

يجب ان تكون الكباري ذات توجه جمالي و خاصة التي تنشأ بداخل المدينة حيث تمثل معلما لهاو قد تكون سياحياو

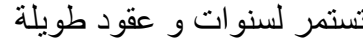
لابد من التفكير في الإستدامه الدائمة لتصميمات الكيات الكباري

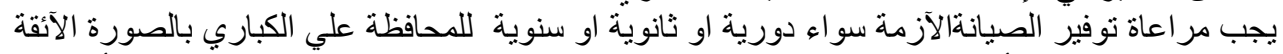

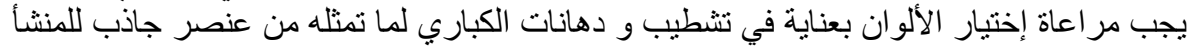

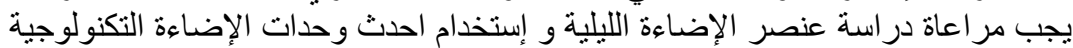
مر اعاة توفير أماكن انتظار سيارات مناسب بالمناطق المتنو عة بالمدينة لتسهيل حركة و إستخدامات الكية الكباري

مو اصفات الجسور و الأنفاق والعبارات ومعابر المشاة في المناطق الحضرية "، وزارة الثئون البلدية والقروية

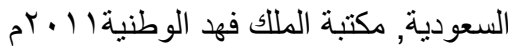

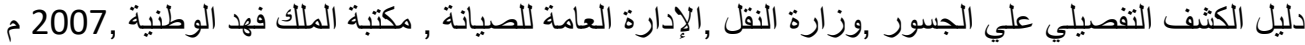

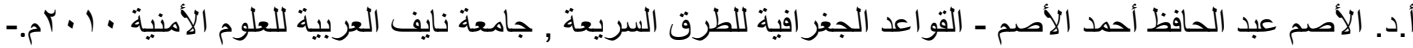

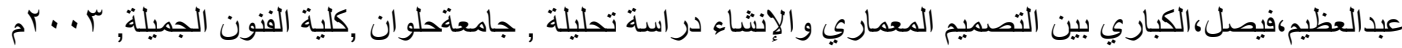

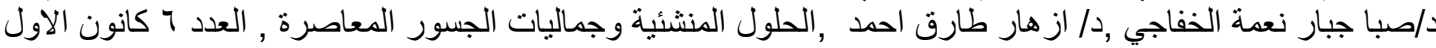

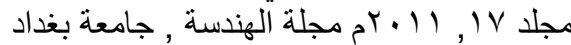

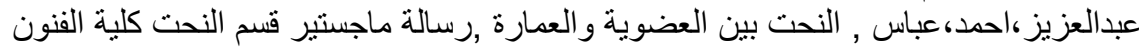

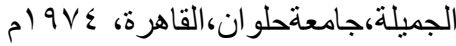

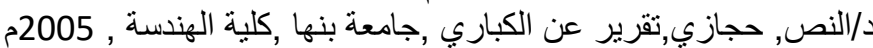
دـ.أسامر زكريا أحمد ,أسس تصميم كباري المشاة داخل النسيج العمر اني لتحقق القيمة الجمالية:

-Billington, D.P. 1983. The Tower and the Bridge. New York: Basic Book -

-BILINGTON, D. P., The Art of Structural Design: A Swiss Legacy, New Haven: Yale University Press, 2003

-GAUVREAU, P., Innovation and aesthetics in bridge design, Canadian Civil Engineering 2007 


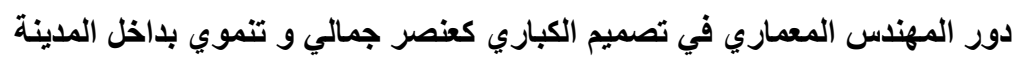

34TH INTERNATIONAL SYMPOSIUM ON BRIDGE AND STRUCTURAL ENGINEERING, VENICE, $-2010$

1-90 Architectural Design Standards, revised edition.Washington State Department of Transportation, -Olympia,Dec. 1986.

Bridge Architecture: The Good, the Bad, and the Ugly, R. Ralph Mays, Washington State Department of -ransportation 2003

A Look at Bridges: A Study of Types, Histories, and the Marriage of Engineering and Architecture ,Connecticut -College

-Gottemoeller, F. 1998. Bridgescape, The Art of Designing Bridges. John Wiley \& Sons, Inc., New York, NY., $276 \mathrm{p}$

-Chris van Uffelen , MASTERPIECES: BRIDGE ARCHITECTURE + DESIGN ,2009

Prof Nadja Kurtovic Folic ,University of Novi Sad ,Faculty of technical sciences ,Trg D. Obradovica 6 - Novi -Sad-

-Serbia THE CONTRIBUTION OF THE ARCHITECTS TO THE BRIDGE AESTHETICS

https://www.albayan.ae/paths/books/20

www.momra.gov.sa/files/bridges

https://www.amazon.com/Tower-Bridge-New-Structural-Engineering

https://en.wikipedia.org/wiki/Millennium_Bridge,_London

https://theconstructor.org/structures/types-bridge-railings

Where, Rn is Reynold's number. 